\title{
Do delays in expected loss recognition affect banks' willingness to lend?
}

\author{
Anne Beatty, Scott Liao \\ Version Post-print/Accepted Manuscript \\ Citation Beatty, A. and Liao, S., 2011. Do delays in expected loss recognition \\ (published version) affect banks' willingness to lend?. Journal of accounting and economics, 52(1), \\ pp.1-20. doi: 10.1016/j.jacceco.2011.02.002. \\ Copyright/License \\ (c) $(1)$ This work is licensed under the Creative Commons \\ International License. To view a copy of this license, visit \\ http://creativecommons.org/licenses/by-nc-nd/4.0/.
}

How to cite TSpace items

Always cite the published version, so the author(s) will receive recognition through services that track citation counts, e.g. Scopus. If you need to cite the page number of the author manuscript from TSpace because you cannot access the published version, then cite the TSpace version in addition to the published version using the permanent URI (handle) found on the record page.

This article was made openly accessible by $U$ of $T$ Faculty. Please tell us how this access benefits you. Your story matters. 


\title{
Do Delays in Expected Loss Recognition Affect Banks' Willingness to Lend?
}

\author{
Anne Beatty \\ beatty.86@osu.edu \\ Fisher College of Business \\ The Ohio State University \\ 442 Fisher Hall \\ 2100 Neil Avenue \\ Columbus, OH 43210 \\ 614-292-5418 \\ Scott Liao \\ scott.liao@rotman.utoronto.ca \\ Rotman School of Management \\ University of Toronto \\ 105 St. George Street \\ Toronto, ON M5S 3E6 \\ 416-946-8599
}

December 15, 2010

\begin{abstract}
Banks can decrease their future capital inadequacy concerns by reducing lending. The capital crunch theory predicts that lending is particularly sensitive to regulatory capital constraints during recessions, when regulatory capital declines and external-financing frictions increase. Regulators and policy makers argue that the current loan loss provisioning rules magnify this pro-cyclicality. Exploiting variation in the delay in expected loss recognition under the current incurred loss model, we find that reductions in lending during recessionary relative to expansionary periods are lower for banks that delay less. We also find that smaller delays reduce the recessionary capital crunch effect. These results hold across management quality partitions.
\end{abstract}

We would like to thank an anonymous reviewer, Daniel Benesh, Jere Francis, Michelle Hanlon, Bob Magee, Rodrigo Verdi, Ross Watts (the editor), Joe Weber and seminar participants at Indiana University, Northwestern University, SMU, MIT, University of Toronto, and the University of Missouri for helpful comments. 


\section{Introduction}

Banks facing external-financing frictions, such as the Myers and Majluf (1984) adverseselection problem, cannot immediately restore equity capital reductions caused by economic downturns. The capital crunch theory predicts that capital adequacy regulation combined with market imperfections leads to pro-cyclical bank lending. Specifically, banks reduce lending more to avoid potential future violations of regulatory capital minimums during recessions relative to expansions. In a May 7, 2009 speech entitled "Lessons of the Financial Crisis for Banking Supervision," Ben Bernanke, Federal Reserve Bank (FED) chairman, argued that "working to mitigate pro-cyclical features of capital regulation and other rules and standards" is an important element in enhancing the stability of the financial system as a whole.

Regulators and policy makers argue that current loan loss provisioning rules reinforce the pro-cyclical capital effect. The extent to which the recognition of expected losses is delayed affects the ability of loan loss reserves to cover credit losses during economic downturns. When loan loss reserves cannot absorb recessionary credit losses, greater provisioning is required and reduces capital adequacy, potentially accentuating capital pro-cyclicality. ${ }^{1}$ Regulators argue that current rules contribute to pro-cyclicality by delaying the recognition of expected losses. Given these macro-economic concerns with the current incurred-loss provisioning method, which is used throughout most of the world, regulators and policy makers are considering alternative loan loss methods.

The Financial Stability Forum (FSF) Report (2009) discusses difficulties banks experiencing extensive losses face in replenishing their capital. ${ }^{2}$ The report states that during

\footnotetext{
${ }^{1}$ As used by Bernanke, pro-cyclicality is the exaggeration of cyclical tendencies in aggregate economic activity.

${ }^{2}$ The FSF was founded in 1999 by the G7 Finance Ministers and Central Bank Governors to recommend new structures to promote stability in the international financial system.
} 
economic downturns "a weakened financial system cannot absorb further losses without causing amplifying retrenchment." The FSF identifies loan loss provisioning as one of three policy action priorities addressing the driving forces of positive feedback between the financial and real sectors. Comptroller of the Currency John C. Dugan's remarks on March 2, 2009 to the Institute of International Bankers entitled "Loan Loss Provisioning and Pro-cyclicality" reflect these concerns. He argues that the limitation on judgment in applying the current "incurred loss model,"3 was a fundamental constraint leading "loan loss provisioning [to] become decidedly pro-cyclical, magnifying the impact of the [current economic] downturn."

While regulators argue that delaying the recognition of expected losses exacerbates procyclicality, the empirical evidence is limited. We exploit cross-sectional differences in the application of the incurred loss model to examine whether delays in expected loss recognition affect pro-cyclicality of banks' lending. ${ }^{4}$ Based on the capital crunch theory, we first hypothesize a higher association between lending and capital ratios in recessions versus expansions in the presence of numerical capital adequacy regulation. Our primary analysis focuses on the period after implementation of the 1988 Basel Risk Based Capital Regulation and the Federal Depository Insurance Corporation Improvement Act of 1991 (FDICIA). The effect of these regulations likely differed with bank size, thus we also examine whether the capital crunch effect differs for large versus small banks.

\footnotetext{
${ }^{3}$ Dugan (2009) states "the savvier institutions that worked hard with the process found ways to exercise and document judgmental factors that allowed them to take provisions that were higher than historical experience would imply. Nevertheless, it is clear to me that a number of banks and their auditors have not been adequately aware of the degree to which judgmental, forward-looking factors may be used to justify provisions. It is also clear to me that a number of other banks have felt constrained in their ability to adequately document the use of such judgmental factors."

${ }^{4}$ We rely on arguments by the FSF (2009) and Dugan (2009) that the incurred loss approach allows for flexibility and management judgment. Bushman and Williams (2009) also exploit variation under the current incurred loss framework across countries.
} 
Based on regulators' arguments that higher recessionary provisioning increases banks' future capital inadequacy concerns, we hypothesize a greater reduction in recessionary lending for banks with a greater versus smaller delay in expected loss recognition. Furthermore, we predict that the lending-capital ratio link during recessions is higher for banks with a greater delay. Finally, to corroborate the effect of provisioning on pro-cyclicality, we also examine how equity changes unrelated to the provision differ for banks with greater versus smaller delays during recessions versus expansions, to better understand how provisioning differences affect lending pro-cyclicality. We hypothesize that banks that delay expected loss recognition less may raise more capital or reduce dividends to maintain their regulatory capital ratios during expansions.

In supplemental tests, we examine whether capital constraints arise directly from regulatory capital requirements by conducting the same analysis using a period prior to explicit capital regulation. Specifically, we examine the twenty-year period prior to the introduction of the first explicit regulatory requirements in December of 1981.

We test our hypotheses using three different measures of delay in expected loss recognition. The first is a loan loss specific metric based on Nichols et al. (2009). This measure is the incremental explanatory power of future and contemporaneous nonperforming loans, beyond that of past nonperforming loans, in explaining the current loan loss provision. It has the advantage of being a direct measure, but the disadvantage of eliminating banks without sufficient time-series data. Our second loan loss specific measure is the ratio of the loan loss allowance to total nonperforming loans. Although a less direct measure, it does not require time-series data. These two loan loss specific measures however lack the necessary data for estimation during the pre-regulatory period. Our third measure uses Khan and Watts' (2009) approach to calculate 
bank-quarter Basu (1997) loss recognition estimates. Although the market-based approach is somewhat controversial, it has the advantage of varying through time and not requiring a firmspecific time-series of observations. This measure is estimable during both the Basel and preregulatory periods, but provides a general rather than loan loss specific metric. We attempt to validate each of these two less direct measures by examining the extent to which each of them is associated with current and future non-performing loans.

We use bank COMPUSTAT data to test our hypotheses because the data includes both the Basel and the pre-regulatory periods for publicly traded banks for whom it is possible to estimate our market based loss recognition measure. Our primary sample period begins in $1993,{ }^{5}$ the first year that risk based capital requirements were fully implemented. ${ }^{6}$ This sample includes 24,788 bank-quarter observations, representing 1,370 banks. During this period, the NBER defines two recessionary periods: 1) from March 2001 to December 2001 and 2) from December 2007 to June 2009. Based on the NBER's classification, we treat 2001:2-4, 2008:1-4 and 2009:12 as recessionary periods, resulting in 2,763 bank-quarters during recessions.

A challenge in testing the capital crunch hypothesis is separating supply from demand effects. We follow Kishan and Opiela (2006) and Kashyap and Stein (2000) by using bank size as a differentiating characteristic related to banks' ability to supply loans but unrelated to loan demand to identify supply versus demand. We also argue that delay in expected loss recognition is related to loan supply but not loan demand, which provides a second identification strategy. Finally, following Bernanke and Lown (1991), we also include the change in unemployment rate as well as many other macro variables to control for loan demand when estimating our models.

\footnotetext{
${ }^{5}$ We do not examine the period from 1982 through the third quarter of 1993 because regulatory requirements were not consistent and macro-economic conditions did not vary sufficiently during this period.

${ }^{6}$ We start with the third quarter because risk-based capital ratios were not reported in COMPUSTAT until that time.
} 
Although our measures of delay in expected loss recognition help separate supply from demand, they may introduce a second identification problem related to distinguishing between the accounting effects and overall bank management quality. Well-managed banks may cut loans less in recessions and may also have a smaller delay in expected loss recognition. Based on DeYoung (1998), we argue that well managed banks are those with a higher return on lending relative to other banks in a given period. We separate banks at the median based on lagged quarterly pre-provision return on loans to separate management quality from accounting quality. If the provisioning effect holds across both management quality partitions, then it is suggested that the measures of delay in expected loss recognition are capturing accounting quality as distinct from management quality.

Consistent with the capital crunch hypothesis, we find a higher association between lending and risk-based capital ratios during recessions. We also find a stronger capital crunch effect for banks with assets greater than $\$ 500$ million. Consistent with the pro-cyclical provisioning hypothesis we observe a greater reduction in lending during recessions by banks that delay expected loss recognition more compared with banks that delay less. Additionally, we find that the smaller delay banks demonstrate less association between capital and lending. These results hold for both our loan loss specific market measures and management quality partitions. We also find that smaller delay banks increase their pre-provision equity more during expansions and that greater delay banks' pre-provision equity is reduced more during recessions. Finally, we find no evidence of a capital crunch during the pre-regulatory period.

In addition to shedding light on the current policy debates, we contribute to the banking and accounting literatures. Our finding of a greater association between banks' capital ratios and lending during the two post Basel/FDICIA recessions is consistent with evidence from previous 
recessions. However, our finding that the capital crunch is more (rather than less) serious for banks with total assets more than $\$ 500$ million, relative to smaller banks, after Basel/FDICIA implementation contrasts with evidence from prior periods. We contribute to the accounting literature by finding that financial reporting quality not only affects industrial firms' borrowing and investing behaviors (e.g., Biddle and Hilary, 2006; Bharath et al., 2008), but also impacts banks' willingness to lend. This affects the overall capital availability on the macro level. Specifically, we show banks with greater delays in recognition of expected loss reduce their lending by more than $2 \%$ on average during recessions. In addition, we find that delaying expected loss recognition increases the importance of banks' capital ratios in their lending decisions during recessions by more than $20 \%$. Further, we contribute to the literature examining the importance of financial reporting quality in recessions (e.g., Hilary, 2008), by documenting that the effect of the provision on the relation between regulatory capital and lending differs during expansions versus recessions.

The rest of the paper is organized as follows. Section 2 provides the background. We develop hypotheses in section 3. We describe our sample and research design in Section 4. We discuss results in Section 5 and supplemental analyses in Section 6. Section 7 concludes our work.

\section{Background}

\subsection{Banking regulation}

Before 1981 the U.S. had no specific numerical capital adequacy standards. Instead, bank regulators' judgment determined capital adequacy. In December of 1981, the three primary U.S. bank regulators (i.e., FED, OCC and FDIC) implemented explicit numerical capital requirements for all but the largest multinational banks. However, the numerical requirements 
differed by bank size and the three regulators did not use the same capital adequacy ratio. ${ }^{7}$ By

1985 all banks regardless of size were subject to a uniform capital requirement with a common definition of regulatory capital used by the three regulators. Capital adequacy was largely determined using the primary capital to average total assets ratio. ${ }^{8}$ These requirements remained in place until Basel risk based capital rules were phased-in during the fourth quarter of 1990.

The Basel Accord changed both the numerator and denominator of the capital adequacy ratio. The Basel Tier 1 capital ratio numerator still includes common equity, perpetual preferred stock and minority interests, but deducts goodwill and other intangibles and no longer adds back the loan loss allowance. The denominator is risk-weighted assets ${ }^{9}$ calculated after assigning assets to one of four categories with weights of $0 \%, 20 \%, 50 \%$ or $100 \%$, depending on the risk associated with the assets. ${ }^{10}$

FDICIA was enacted to change federal oversight of depository institutions. ${ }^{11}$ FDICIA's "Prompt Corrective Action" section, requiring that regulators classify banks into one of five capital adequacy categories, ${ }^{12}$ was designed to restrict regulatory discretion including the existing "Too big to fail" policies. The prompt corrective action requirements in FDICIA apply to all banks(regardless of size) but may have had the greatest effect on large banks that were

7 The FED and OCC required minimum total capital ratios of $7 \%$ for community banks and of $6 \%$ for regional banks with assets $>\$ 1$ billion, but did not subject multinationals with assets $>\$ 15$ billion to capital requirements. The FDIC required a $6 \%$ capital ratio regardless of size, but the minimum applied to a primary capital ratio rather than to a total capital ratio.

${ }^{8}$ The primary capital components were: common equity, perpetual preferred stock, minority interests, mandatory convertible instruments, and the loan loss allowance.

${ }^{9}$ U.S. banks' tier 1 capital ratio to risk weighted assets must exceed $4 \%(8 \%)$ to be adequately (well) capitalized.

${ }^{10}$ The $0 \%$ category includes cash, gold and claims unconditionally guaranteed by the U.S. or OECD central governments. The $20 \%$ category includes short-term claims guaranteed by U.S. and foreign banks and claims conditionally guaranteed by the U.S. or OECD central governments. The $50 \%$ category includes loans fully secured by first liens on 1-4 family residential properties and loans to state and local governments. The $100 \%$ category includes all other assets not assigned to the lower risk weighted categories. Off-balance sheet items are also included in the calculation of risk-weighted assets based on a credit conversion factor that also varies from 0 to $100 \%$.

${ }^{11}$ Under FDICIA, banks failing to meet the capital requirement are not allowed to pay dividends. In addition, bank regulators must intervene and require a capital restoration plan, limit asset growth and restrict new lines of business.

${ }^{12}$ These categories include three undercapitalized categories based on undercapitalization severity. 
more likely to receive regulatory forbearance. In addition, FDICIA's "Early Identification of Needed Improvements in Financial Management" section requires the establishment of an audit committee and internal control evaluation and reporting systems. When adopted in 1993, this section applied only to banks whose assets exceeded $\$ 500$ million. This threshold was increased to $\$ 1$ billion in December of 2005 . If these provisions restricted banks' ability to manage their reported regulatory capital, then this may have also increased large banks' concerns about falling below regulatory capital minimums. ${ }^{13}$

\subsection{Capital crunch due to the risk of future capital inadequacy and loan default shocks}

Capital market imperfections can restrict bank lending during recessions. Van den Heuvel (2009) extends Stein's (1998) liquidity-based adverse-selection model of reduced recessionary lending by providing a distinct model of reduced lending arising from recessionary decreases in bank capital. Specifically, he argues that banks with sufficiently low equity will reduce lending due to capital requirements and costs of raising new equity. ${ }^{14}$ His model explicitly shows that a reduction in lending can occur even when the capital requirement is not currently binding because low-capital banks may optimally forgo profitable lending opportunities now to lower the risk of future capital inadequacy. He notes the importance of this feature, given that most U.S. banks are not at the capital constraint at any given time.

Van den Heuvel (2009) also models the effect of loan default shocks on new lending. He shows that although unconstrained banks' lending is unaffected by loan charge-offs, which is equivalent to loan loss provisioning in his model, lending by constrained banks declines and

\footnotetext{
${ }^{13}$ Altamuro and Beatty (2010) find that the FDICIA internal control provisions result in decreased loan loss provisioning discretion making the provision less conservative for banks affected relative to unaffected banks.

${ }^{14}$ His model assumes that: capital adequacy regulations exist, it is costly to raise new equity, and the cost of retaining equity is high relative to other forms of financing. The model assumes this cost arises from tax disadvantages of equity versus debt, but acknowledges that there are other reasons why equity is more expensive.
} 
stays lower for several periods in response to increased loan loss provisioning. He also concludes that "an important implication of the relevance of the bank's capital adequacy is that shocks to bank profits, such as loan defaults, can have a persistent impact on lending [especially for banks with capital adequacy concerns]. This is akin to the 'financial accelerator' mechanism that arises in firm models with imperfect financial markets, such as Bernanke, Gertler and Gilchrist (1999)." Since recessions lead both to increased capital concerns and to shocks to profits for banks that do not anticipate increased loan defaults and instead delay expected loss recognition, we argue that banks that delay expected loss recognition are more likely to cut lending during recessions.

\subsection{Pro-cyclicality and the incurred loss method of loan loss provisioning}

The FSF (2009) argues that the pro-cyclical effect on lending of loan defaults, combined with capital market imperfections and capital regulation modeled by Van den Heuvel (2009), may vary with the loan loss provisioning method. The FSF argues that the pro-cyclicality of the loan loss provision may arise either from misapplication or inherent properties of the incurred loss model used in both FASB and IASB standards. ${ }^{15}$ This model requires impairment recognition when a loss is probable based on past events and conditions at the financial statement date. Under the incurred loss model it is inappropriate to consider possible or expected losses based on the trends that may lead to additional losses. ${ }^{16}$

\footnotetext{
15 Prior to the May 1993 adoption of FAS 114, FAS 5 provided impairment guidance for all receivables including loans. FAS 114 provides more specific guidance for loans individually deemed to be impaired because it is probable that not all interest and principal payments will be made as scheduled.

${ }^{16}$ In contrast, Handorf and Zhu (2006) find a positive correlation between provisions and concurrent GDP changes and argue their "empirical tests do not support the claim that bank loan-loss provisioning is pro-cyclical." They claim U.S. banks use discretion to "overstate loan-loss provisions during economic expansions, and vice versa." They believe this discretion could reflect either prudent loan loss provisioning or earnings management. Although they find no evidence of pro-cyclical provisions, their sample includes only one recession (1990:3-4 - 1991:1) predating FAS 114 and the full Basel implementation. Therefore, their findings do not address the current incurred
} 
In a March 2009 joint meeting background paper, the FASB/IASB staff discusses their belief that there is a common misperception with the incurred loss method. Specifically, they state that the requirement under this approach of "objective evidence of impairment as a result of one or more events that occurred after the initial recognition of the asset" is often interpreted to mean that loss recognition is deferred until the borrower actually defaults. The staff states that the approach actually should be interpreted to indicate that "default is the latest date on which impairment should be recognized." Consistent with this view, in their report addressing procyclicality in the financial system, the FSF recommends that:

The FASB and IASB should issue a statement that reiterates for relevant regulators, financial institutions, and their auditors that existing standards require the use of judgement to determine an incurred loss for provisioning of loan losses.

This recommendation allows for the possibility that pro-cyclicality in loan loss provisioning could be reduced merely by proper application of the incurred loss model. Our research design hinges on this possibility and the cross-sectional variation in the application of this method. ${ }^{17}$

In addition, $\mathrm{SAB} 102$ requires banks to document that loan loss provisioning is consistent with GAAP, which Dugan (2009) argues limits the use of judgment in loan loss recognition. ${ }^{18}$ Provisioning discretion may also have been reduced by SAB 102's call for reductions in differences between estimated losses and subsequent charge-offs.

\subsection{Identification of loan supply versus loan demand effects}

loss model debate. Their sample period also ends before the issuance of Staff Accounting Bulletin (SAB) 102 .

${ }^{17}$ In response to criticisms of the current incurred loss model, the IASB issued an exposure draft on impairment of financial assets in November 2009.

${ }^{18}$ The Federal Financial Institutions Examination Council issued interagency guidance concurrently with SAB 102. 
Kashyap and Stein (2000) review the difficulties identifying lending supply versus demand. Based on Bernanke and Gertler (1995), they argue that comparing aggregate bank lending to other forms of external financing is not a valid identification method. They state that to "make further progress on this difficult identification problem, one has to examine lending behavior at the individual bank level, ... [and] explore cross-sectional differences in the way that banks with varying characteristics respond to shocks." Kishan and Opiela (2006) note that for individual bank level analyses, loan supply can be identified by separating banks by differential characteristics tied to their ability to supply loans, but not to their loan demand. Kashyap and Stein (2000) use bank size and liquidity as two such characteristics.

\subsection{Management quality}

The extent to which bank lending is pro-cyclical may also depend on the quality of bank management. The lending of more properly managed banks may be less affected by capital constraints during economic downturns. Bank regulators monitor banks not only based on their capital ratios but also based on management quality, which represents the $M$ in the CAMEL ratings. Using confidential information on the regulatory CAMEL ratings, DeYoung (1998) finds regulators' management quality assessments correlate with multiple bank characteristics, among which ROA is most highly correlated with management quality with a simple correlation of 45\%. Based on DeYoung (1998), we argue that well managed banks will be those that have a higher return before provision on loans relative to other banks in a given period.

\section{Hypotheses development}

The capital crunch theory suggests that capital market imperfections making it difficult for banks to raise external equity capital will lead banks concerned about potential future capital constraints to reduce their lending during recessions. Based on this theory our first hypothesis is: 


\section{H1: the association between banks' regulatory capital ratios and bank lending will be greater during recessionary relative to expansionary periods.}

Bernanke and Lown (1991) test for a capital crunch during the 1990:2-1991:1 recession using both a state-level analysis and a bank-level analysis for New Jersey. ${ }^{19}$ They find that loan growth during that recession is positively related to the beginning-of-the-period capital to assets ratio. Allowing their estimates to differ by bank size, they find statistical significance only for banks with assets less than $\$ 1$ billion.

Their capital crunch finding for small but not large banks is consistent with Kishan and Opiela's (2000) findings that monetary policy affects lending to a greater degree for small undercapitalized than for larger well-capitalized banks during a period spanning multiple regulatory capital regimes (1980:1 - 1995:4). However, Kishan and Opiela (2006) find that the difference in loan supply responsiveness to expansionary monetary policy between high versus low capital banks holds across all size categories in the post Basel/FDICIA period (1990:3 1999:4). Kishan and Opiela (2006) argue that their results suggest "a more stringent effective capital constraint in the post-Basel/FDICIA period." Bernanke and Lown (1991) and Kishnan and Opiela's (2006) findings that a greater capital crunch for smaller banks relative to larger banks during the pre-Basel/FDICIA period may be attributable to looser application of regulatory capital regulations to larger banks deemed "Too big to fail" in the pre-Basel/FDICIA regime, or to the extent to which small banks have more difficulty raising external regulatory capital during recessions.

\footnotetext{
${ }^{19}$ In a statement before a subcommittee of the U.S. House of Representatives, made on May 8, 1991, Richard F. Syron, then President of the Boston FED used the term capital crunch to distinguish a reduction in bank lending caused by a loss of bank capital from a credit crunch that results from a reduction in bank deposits.
} 
The prompt corrective action requirements in FDICIA designed to end the existing "Too big to fail" policy may have increased large banks' concerns about falling below regulatory capital minimums, and thus increased the extent to which they were likely to be subject to a capital crunch during recessions. In addition, the FDICIA internal control provisions, applying only to larger banks whose assets exceeded $\$ 500$ million ( $\$ 1$ billion after December 2005), restrict large banks' ability to manage their reported regulatory capital and may have also increased their concerns about falling below regulatory capital minimums, further increasing the extent to which they were likely to be subject to a capital crunch.

Because of these conflicting predictions about the effect of bank size we do not predict whether large banks will be more or less likely to suffer from a capital crunch, but do examine whether there is a difference for large versus small banks. Our second hypothesis is:

\section{H2: the association between banks' regulatory capital ratios and lending during recessionary relative to expansionary periods differs for small versus large banks.}

Delaying the recognition of expected losses will lead to an increase in the required provision during economic downturns. This increase in the loan loss provision will decrease banks' reported income and their Tier 1 regulatory capital. Van den Heuvel's (2009) theory that banks may optimally forgo profitable lending opportunities now to lower the risk of future capital inadequacy suggests that the expected increase in the loan loss provision during recessions may lead to lower recessionary lending for banks with greater delays in expected loss recognition. This suggests that the pro-cyclicality of the lending is higher for these banks. Our third hypothesis is:

\section{H3: lending during recessionary relative to expansionary periods is lower for banks with greater delays in expected loss recognition than for those with smaller delays.}


In addition to this direct effect on lending activity, Van den Heuvel (2009) argues that the impact of loan losses is larger for poorly capitalized banks because of an increased likelihood that the bank will be faced with binding regulatory or financial constraints. In addition, larger loan loss provisions decrease both income statement and balance sheet strength, therefore they may increase the costs of external equity financing even further during recessions. Based on these arguments, we expect that the delay in expected loss recognition may also affect the association between banks' reported capital ratios and their lending during recessionary periods.

Our fourth hypothesis is:

H4: the association between banks' regulatory capital ratios and lending during recessionary relative to expansionary periods will be greater for banks with greater delays in expected loss recognition than for those with smaller delays.

Ceteris paribus, we argue that in expansionary periods banks with smaller delays in expected loss recognition are more likely to have capital inadequacy concerns compared to banks with longer delays because the current provisions of those with smaller delays incorporate future economic downturn defaults. To alleviate these concerns, banks with smaller delays in expected loss recognition may take actions to build-up capital, such as raising equity or reducing dividends, during expansions when these actions are relatively cheaper. By taking these actions smaller delay banks can increase regulatory capital, thereby mitigating recessionary lending cuts. As a consequence, a stronger pro-cyclical effect for banks with greater delay compared to banks with smaller delays will arise. Based on these arguments, our fifth hypothesis is:

H5: increases in pre-provision equity in expansionary periods are greater for banks with smaller delays in expected loss recognition than for those with greater delays.

\section{Sample and research design}

\subsection{Sample selection}


Our primary sample contains COMPUSTAT banks with the necessary data during the period 1993:3-2009:2. We chose 1993 because this is the first year of full implementation of risk based capital and FDICIA. We focus on COMPUSTAT banks because data is available for the pre-regulatory period we examine in supplemental tests and because our market-based loss recognition measure requires publicly traded banks. To address concerns that our analyses might be affected by mergers and acquisitions, we exclude all observations with non-loan asset growth exceeding $10 \%$ in any quarter. Our sample includes 24,788 bank-quarter observations, representing 1,370 banks. During this period, the NBER defines two recessions: 1) March 2001 December 2001 and 2) December 2007 to the June 2009. Our sample includes 2,763 bankquarters during these two recessions (2001:2-4, 2008:1-4 and 2009:1-2).

\subsection{Lending model}

To test the capital crunch hypothesis we examine differences in the association between quarterly lending changes and beginning-of-the-quarter regulatory capital ratios during recessions versus expansions. Consistent with Bernanke and Lown (1991), Kishan and Opiela (2000 and 2006), and Kashyap and Stein (2000), we use OLS estimation of the following reduced form loan supply model to test $\mathbf{H 1} .^{20}$ All continuous variables are winsorized at the top and bottom $1 \%$, and all t-statistics in multivariate regressions are clustered by calendar quarters.

$$
\begin{aligned}
\Delta \text { Loan }= & \beta_{0}+\beta_{1} \text { Recession }+\beta_{2} \text { Capital R1 }+\beta_{3} \text { Capital R1*Recession }+ \\
& \beta_{4} \Delta U N R A T E+\beta_{5} \text { Size }+\beta_{6} \text { Deposits }+\beta_{7} \Delta \text { Capital R } 1+\beta_{8} \sigma_{r e t}+\varepsilon
\end{aligned}
$$

where

\footnotetext{
20 Angrist and Krueger (2001) argue that "Concerns about weak instruments can be mitigated most simply by looking at the reduced form equation, that is, the ordinary least squares regression of the dependent variable of interest on the instruments and exogenous variables. These estimates are unbiased, even if the instruments are weak. Because the reduced form effects are proportional to the coefficient of interest, one can determine the sign of the coefficient of interest. Most importantly, if the reduced form estimates are not significantly different from zero, the presumption should be that the effect of interest is either absent or the instruments are too weak to detect it."
} 
$\Delta$ Loan: $\quad$ Change from the beginning to the end of the quarter in the natural log of loans (COMPUSTAT "Intalq").

Recession: An indicator variable equal to one for periods between 2001Q2 and 2001Q4, and periods between 2008Q1 and 2009Q2; zero, otherwise.

Capital R1: The Tier 1 risk-adjusted capital ratio (COMPUSTAT “capr1q") at the beginning of the quarter, divided by 100.

$\triangle U N R A T E:$ The change in the quarterly unemployment rate. Data is collected from the website of Department of Labor: http://www.bls.gov/

Size: $\quad$ The natural log of lagged total assets (COMPUSTAT "atq").

Deposits: $\quad$ Lagged total deposits (COMPUSTAT “dptcq") divided by total loans.

$\triangle$ Capital R1: Quarterly change in Capital R1, that is the beginning Capital R1 minus lagged beginning Capital R1.

$\sigma_{\text {ret }} \quad$ Standard deviation of daily return of the previous quarter.

In addition to the test variables, we follow Bernanke and Lown (1991) by including $\triangle U N R A T E$ to control for bank loan demand in Equation (1). We also include bank asset size to control for unspecified size effects. Further, we include Deposits to capture banks' access to deposit financing, which Ivashina and Scharfstein (2009) argue affects loan supply during recessions. Following Bernanke and Lown (1991), we also include $\Delta$ Capital Rl as a control variable. Finally, we include the standard deviation of stock returns as a measure of risk because the risk-based capital ratio will only imperfectly capture differences in asset risk across banks. ${ }^{21}$

We predict a negative coefficient on Recession if loan supply declines during recessions for reasons other than capital and liquidity constraints. Further, if external financing is not frictionless, and banks are concerned that they might violate regulatory capital requirements, then the coefficient on Capital $R l$ is expected to be positive. That is, banks will lend more when they are less concerned that the new lending will result in a regulatory capital violation. In addition, based on H1, we expect that the coefficient on Capital Rl*Recession will be positive. We expect the regulatory capital buffer to be more important during recessions for a variety of

\footnotetext{
${ }^{21}$ We also control for the Tier 2 capital ratio and the results continue to hold.
} 
reasons including lower profitability, more expensive external equity, and increased regulatory scrutiny. We predict a negative coefficient on $\triangle U N R A T E$ because demand for bank loans decreases as the macro-economic conditions worsen. Finally, consistent with Ivashina and Scharfstein (2009) we expect the coefficient on Deposits to be positive. We include Size, $\triangle$ Capital $R 1$, and $\sigma_{r e t}$ as control variables and therefore do not predict the sign of the coefficients on these variables.

To test how bank size affects the extent of the capital crunch, we compare the coefficients on Capital R1*Recession for banks with higher versus lower total assets. We begin by comparing banks with total assets greater than $\$ 500$ million and those below $\$ 500$ million. We chose the $\$ 500$ million cut-off because it is consistent with the cut-off in the FDICIA internal control provisions. However, based on $\mathbf{H 2}$, we do not have a directional prediction.

We test $\mathbf{H 3}$ and $\mathbf{H 4}$ by investigating the difference in the coefficients on Recession and Capital $R 1 *$ Recession in Equation (1) between firms with smaller delays in expected loss recognition versus those with greater delays. Specifically, we interact Recession and Capital $R I *$ Recession with an indicator variable <Delay for bank-quarter with smaller delays in expected loss recognition (see 4.4.1 and 4.4.2 for detail). Based on $\mathbf{H 3}$ and $\mathbf{H 4}$, we expect the coefficients on Recession (Capital RI*Recession) to be lower (higher) for greater delay banks. That is, we expect the coefficients on Recession* $<$ Delay (Capital RI*Recession*<Delay) to be positive (negative). We construct three measures to capture the extent of delays in expected loss recognition: two loan loss specific measures and a general market measure, discussed in Sections 4.4.1 and 4.4.2.

To ensure that these results are not driven by differences in bank management quality that are unrelated to accounting quality, we separate banks based on above versus below median 
quarterly lagged pre-provision return on loans. If the results on the delay in expected loss recognition hold across both management quality partitions, this suggests that our measures are capturing accounting quality as distinct from general management quality.

\subsection{Change in pre-provision equity}

There are a number of actions banks could take to increase equity including cutting dividends, raising equity, and cutting compensation. Instead of examining each possible action banks can take, we examine an aggregate change in equity with an adjustment of current provisions to investigate banks' capital change. We estimate the following OLS model to test

H5:

Where

$$
\begin{aligned}
\Delta C E=\beta_{0} & +\beta_{1} \text { Recession }+\beta_{2}<\text { Delay }+\beta_{3} \text { Recession } *<\text { Delay } \\
& +\beta_{4} \text { Capital Rl }+\beta_{5} \Delta U N R A T E+\beta_{6} \text { Size }+\beta_{7} \text { Deposits }+\varepsilon,
\end{aligned}
$$

$\triangle \mathrm{CE}$ :

Measured as the natural log of common shareholders' equity of quarter $t$ with loan loss provisions added back (COMPUSTAT "ceqq" $+0.6 *$ COMPUSTAT "pllq") minus the natural $\log$ of lagged common shareholders' equity (COMPUSTAT "ceqq" at quarter $\mathrm{t}-1$ ).

Recession: $\quad$ An indicator variable equal to one for periods between 2001Q2 and 2001Q4, and periods between 2008Q1 and 2009Q2; zero, otherwise.

<Delay: An indicator variable for banks with smaller delays in loss recognition compared to the median of the quarter (see 4.4.1 and 4.4.2 for details.)

Capital R1: $\quad$ Tier I risk-adjusted capital ratio (COMPUSTAT "capr1q") at the beginning of the quarter, divided by 100 .

$\triangle$ UNRATE: $\quad$ The change in the quarterly UMEMPLOYMENT rate.

Size: $\quad$ The natural log of total assets (COMPUSTAT "atq") at the beginning of the quarter.

Deposits: $\quad$ Total deposits (COMPUSTAT “dptcq) divided by total loans, at the beginning of the quarter.

Consistent with the cost of raising equity being higher during recessions we expect a negative coefficient on the Recession variable. If smaller delay banks raise more equity during non-recessionary periods to compensate for higher provisioning, then we expect the coefficient on $<$ Delay to be positive. Finally, since smaller delay banks will perform relatively better during 
recessions, we expect that the increased cost of raising equity during these periods will be lower for these banks and therefore predict a positive coefficient on the Recession $*<$ Delay variable.

\subsubsection{Loan specific measures of delay in expected loss recognition}

We develop two loan loss specific metrics of delay in expected loss recognition: a flow and a stock measure. The first is based on Nichols et al. (2009) who argue that "more timely" banks recognize provisions concurrently with or in advance of loans becoming nonperforming. In contrast, less timely banks may recognize loan loss provision after loans become nonperforming.

Gambera (2000) shows that future nonperforming loans can be predicted using current macro-economic indicators. Less delayed loan loss provisioning will reflect predicted future problem loans based on current economic conditions. We define the extent to which recognition of expected losses are not delayed as the additional explanatory power of future and current nonperforming loans beyond that of past nonperforming loans in explaining the current loan loss provision. Our metric, which assumes that on average banks can accurately forecast future and concurrent nonperforming loans, uses the actual future and concurrent nonperforming loans to capture the predicted values. We test the sensitivity of our results to this assumption by substituting our estimates of predicted future and concurrent nonperforming loans for actual nonperforming loans. Our measure is the difference in the adjusted R-squared ((4)-(3)) from the following two rolling regressions for each bank-quarter using the observations of the past 3 years. We require 12 observations to run each regression. ${ }^{22}$

Provision $_{t}=\alpha_{0}+\alpha_{1} \Delta N P L_{t-2}+\alpha_{2} \Delta N P L_{t-1}+\alpha_{3}$ Capital RI $_{t}+\alpha_{4} * E B P_{t}+\varepsilon_{t}$

\footnotetext{
${ }^{22}$ We examine the sensitivity of our results to the number of observations required and find that requiring 8 or 10 observations does not change the results.
} 
Provision $_{t}=\alpha_{0}+\alpha_{1} \Delta N P L_{t-2}+\alpha_{2} \Delta N P L_{t-1}+\alpha_{3} \Delta N P L_{t}+\alpha_{4} \Delta N P L_{t+1}+\alpha_{5}$ Capital R1 $_{t}$ $+\alpha_{6} E B P_{t}+\varepsilon_{t}{ }^{23}$

Where:

Provision: $\quad$ Loan loss provision (COMPUSTAT "pllq") divided by lagged total loans (COMPUSTAT "Intalq").

$\triangle N P L$ : $\quad$ Change in non-performing loans (COMPUSTAT "npatq") divided by lagged total loans (COMPUSTAT "Intalq").

Capital R1: The tier one risk-adjusted capital ratio (COMPUSTAT "capr1q") at the beginning of the quarter, divided by 100 .

EBP: $\quad$ Earnings before loan loss provision, defined as (COMPUTAT "piq" plus COMPUSTAT “pllq”, scaled by lagged COMPUSTAT "Intalq”).

In Equations (3) and (4), we also include the beginning-of-quarter capital ratio and earnings before provision to control for banks' incentives to manipulate provision to avoid falling below regulatory requirements or to smooth earnings (Ahmed et al. 1999; Liu and Ryan, 2006; Healy and Wahlen, 1999). Bank-quarters that have one-quarter-lagged difference in Rsquared higher than the median during the quarter are classified as having a smaller delay in expected loss recognition (i.e., the <Delay variable equals 1), otherwise they are classified as having a greater delay (i.e., <Delay equals 0 ).

While this approach is intuitive in capturing the extent of delays in expected loss recognition, it requires time-series data constraining the sample size. Therefore, in addition to this flow measure, we develop a second stock measure that circumvents this shortcoming. In the same spirit of the first approach, we define a smaller delay in expected loss recognition as the ratio of the allowance of loan loss provisions (COMPUSTAT "rclq") divided by nonperforming loans (COMPUSTAT "npatq"). Fitch (2009) argues that the ratio of the allowance to nonperforming loans is a useful measure, if banks are able to recognize expected risk in their

${ }^{23}$ Following Nicholas et al. (2009), we include the contemporaneous change in nonperforming assets in the smaller delay model (EQ 4). However, we also try including this term in the backward looking model. We continue to find the capital crunch and pro-cyclicality results only in greater delay banks, although the difference between smaller and greater delay banks is reduced. 
performing loans as well as recognize the incurred losses in their non-performing loans. Specifically, they state that:

Reserves for impaired loans/impaired loans: The trend of this ratio is important, but its usefulness will relate to how effective a bank is in identifying specific impaired loans. It is also important to recognize that the performing portfolio needs to be reserved against for expected risk as well, although accounting standards may not allow for this.

We expect banks with a smaller delay in expected loss recognition to have recognized more loan provisions relative to nonperforming loans. We confirm this expectation by examining the association between this measure and the changes in nonperforming loans of current and future quarters. Following this reasoning, banks whose lagged ratio is higher (lower) than the median during the quarter are deemed as banks with a shorter (greater) delay in expected loss recognition. $^{24}$

\subsubsection{Market measure of delay in expected loss recognition}

Our market measure is based on Khan and Watts (2009) who use a cross-sectional approach to estimate the firm-year Basu (1997) measure. Since market returns should reflect information about both incurred losses and expected future losses, a greater association between negative returns and current reported net income is consistent with less delayed provisioning. We modify their approach to suit our investigation of bank-quarter lending. We first estimate the following cross-sectional model. Similar to Khan and Watts (2009), we remove bank-quarters with price per share less than $\$ 1$ or negative book value of equity. ${ }^{25}$

$$
\begin{aligned}
N I= & \beta_{0}+\beta_{1} * D+\text { Returns } *\left(\mu_{1}+\mu_{2} M V+\mu_{3} M T B+\mu_{4} L E V\right) \\
& +D * \text { Returns } *\left(\lambda_{1}+\lambda_{2} M V+\lambda_{3} M T B+\lambda_{4} L E V\right)+\varepsilon,
\end{aligned}
$$

where

\footnotetext{
${ }^{24}$ Using a runs test, we find that these two loan loss specific timeliness measures are quite stable through time. We find that over $56 \%$ and $66 \%$ of banks have a z-statistic less than -1.68 , for each measure respectively, suggesting that these measures are stable over time for the majority of banks.

${ }^{25}$ We require at least 20 observations per quarter in each regression estimate.
} 
NI: $\quad$ Net income (COMPUSTAT “niq") divided by lagged market value of equity (COMPUSTAT "cshoq" * share price at the fiscal quarter end).

Returns: Quarterly returns compounded from monthly returns beginning the second month after fiscal quarter end.

$D: \quad$ An indicator variable that equals 1 for negative Returns, and zero otherwise.

$M V: \quad$ Market value of equity, calculated as the natural $\log$ of market value of equity (COMPUSTAT "cshoq" * share price at the fiscal quarter end).

MTB: $\quad$ Market value of equity divided by book value of equity (COMPUSTAT "ceqq").

LEV: $\quad$ Long term debt (COMPUSTAT "dlttq") divided by market value of equity (COMPUSTAT "cshoq" * share price at the fiscal quarter end).

After Equation (5) is estimated, C_SCORE is constructed using the estimated coefficients. $C \_S C O R E$ is defined as $\hat{\lambda}_{1}+\hat{\lambda}_{2} M V+\hat{\lambda}_{3} M T B+\hat{\lambda}_{4} L E V$. By construction, the higher the C_SCORE, the smaller the delay in expected loss recognition. Bank-quarters with onequarter-lagged C_SCORE higher (lower) than the median during the quarter are classified as “smaller delay (greater delay)". ${ }^{26}$

\section{Results}

Univariate comparisons of our overall sample of bank-quarter observations are provided in Table 1 for recessionary versus expansionary periods. Although we observe positive loan growth during both periods, the rate of growth is significantly higher during the expansionary periods. The differences in the other tabulated variables are consistent with what would be expected in periods of contraction versus expansion. Expressly, regulatory capital ratios and earnings before the provision are both lower during recessions, while the provision, changes in nonperforming loans, unemployment rates and standard deviation of returns are higher during recessions than during expansions.

Table 2 displays the Pearson correlations between bank characteristics. Consistent with

\footnotetext{
${ }^{26}$ To better suit our setting, we also adapt the Khan and Watts (2009) model by replacing NI with Provision in EQ5 as the dependent variable. We calculate C-score accordingly and define low (high) C-Score as smaller (greater) delay. We continue to find similar results.
} 
prior studies (e.g., Kishan and Opiela, 2000; Bernanke and Lown, 1991), we find a positive correlation between the capital ratio and growth in loan supply (correlation $=0.068$ ). Also consistent with prior literature (e.g., Ivashina and Scharfstein, 2009) we find that loan supply is positively correlated with deposits (correlation $=0.054$ ). This finding is consistent with liquidity constraining loan supply. We also observe that the change in loans is negatively related to the provision but is not significantly correlated with the $\triangle N P L$.

The empirical results of the test of our first hypothesis of a capital crunch affecting lending during recessions are provided in the first column of Table 3 (Panel A, Overall Sample). Evidence in support of the capital crunch hypothesis for our sample is provided by the positive and significant coefficient on the Capital $R 1 *$ Recession variable. The coefficient on that variable is larger than that on Capital R1, which measures the association of regulatory capital and lending during non-recessionary periods. This indicates that the impact of regulatory capital more than doubles during recessions. This evidence in support of the capital crunch hypothesis during the most recent two recessions is consistent with the results of research examining earlier recessions. The positive coefficient on Deposits provides evidence that liquidity constraints may affect loan growth. We also find that loan growth is lower when the unemployment rate is higher, for larger firms and for firms with a higher standard deviation of returns.

The second and third columns of Panel A of Table 3 present the results of our test of $\mathbf{H 2}$ that the effect of the capital crunch differs for small versus large firms. We show that the capital crunch (i.e., positive coefficient on Capital RI*Recession) occurs only for banks with total assets in excess of $\$ 500$ million. For these banks the effect of capital on lending growth during recessions is significantly higher than during non-recessionary periods. This finding differs from the findings in the prior literature examining pre-FDICIA data. In contrast to the effect of capital, 
we find that deposits are significant in explaining loan growth for both small and large banks.

We further classify large (small) banks into above versus below $\$ 1$ billion ( $\$ 300$ million) in total assets. Table 3 Panel B shows that the capital crunch affects both banks with assets between $\$ 500$ million and $\$ 1$ billion and banks with assets above \$1billion. These findings along with those in Panel A are consistent with FDICIA's prompt corrective action provisions increasing large banks' capital adequacy concerns. In addition, FDICIA's internal control provisions' limits on large banks' discretion over capital and provision management might contribute to this finding.

We report our examination of the properties of our three measures of delay in expected loss recognition in Table 4. In Panel A we show that the change in non-performing loans reflects lagged and concurrent macro-economic conditions. Specifically, both the current and next period's changes in nonperforming loans are positively correlated with current and lagged unemployment and negatively correlated with current and lagged industrial production. These correlations indicate that current economic conditions can be used to predict future and concurrent non-performing loans. This supports the arguments made by Gambera (2000) that that expected future non-performing loans can be predicted using current macro-economic data. In Panel B we examine the association between our stock and market measures of delay in expected loss recognition and future non-performing loans. There is generally a positive association between our beginning-of-the-period measures of shorter delay in loss recognition and the current and one period ahead change in non-performing loans, suggesting that shorter delay banks put more weights on concurrent and future nonperforming loans in determining provisions. This is consistent with these measures differentiating between smaller versus greater delay in expected loss recognition. In Figure 1, we display the trend in the median adjusted R- 
squared for both less delay (EQ4) and more delay (EQ3) models and the difference between the two models for each quarter. We find that our models explain a reasonable portion of the variation in provisions. For instance, the median-of-the-quarter adjusted R-squared for the less delay model ranges from $30 \%$ to $70 \%$ during the sample period. ${ }^{27}$ In addition, following this trend, we show the descriptive statistics of the adjusted R-squared on the bank-quarter basis. We find that there exists significant variation in the explanatory power for each model and, more importantly, in the difference in their adjusted R-squared. This latter finding supports our premise that there is significant variation in the application of the incurred loss model.

The results of our tests examining the effect of delay in expected loss recognition on lending are presented in Table 5. The first column reports the flow measure results, the second column the stock measure results, and the third column the market measure results. Note that in Tables 5, we only report results using banks with total asset greater than $\$ 500$ million since we find that only these banks experience a capital crunch. Consistent with $\mathbf{H 3}$, we find that loan growth is lower during recessions for banks with greater delays in expected loss recognition, compared to those with smaller delays for all of our measures. The difference in lending between more and less delay banks during recessions is economically significant. For example, using the flow measure, greater delay banks cut lending by $2.1 \%$ in recessions, but smaller delay banks only reduce lending by $0.5 \%$. These results suggest that banks with greater delays, which may have greater capital adequacy concerns arising from a need to record higher provisions during recessions, reduce their lending more, potentially to avoid a capital shortage. Finally, all three

\footnotetext{
${ }^{27}$ One interesting observation about this graph is that, for the most current recession, the explanatory power of both models (and the difference between the two models) dips before the recession starts and increase hugely in the recessionary period. We remove this variation from our measure by defining above versus below the median relative to the concurrent quarter.
} 
measures also show evidence consistent with H4. Explicitly, we find that the coefficients on Capital $R I^{*}$ Recession are lower for banks with smaller delays, suggesting that the capital crunch effect is weaker for banks with smaller delays. Again, the difference is economically significant: for greater delay banks the lending-capital ratio sensitivity increases by 0.214 in recessions, but it only increases by 0.076 for smaller delay banks.

The insignificance of the <Delay variable in all three models indicates that during nonrecessionary period the average lending does not differ based on the extent of delays in expected loss recognition. Further evidence consistent with lending being similar during non-recessionary periods for small versus greater delay banks is provided by the lack of significance on Capital $R I *<$ Delay variable in both the flow and the market measure models. This suggests that the sensitivity of lending to regulatory capital does not differ significantly during non-recessionary periods based on the extent to which recognition of expected losses is delayed. Given the consistency in our results across these three measures and the lack of significance in these differences in two of the three models, our results are not likely driven by these differences.

Table 6 reports the results of the effect of delay in expected loss recognition on lending estimated separately for well versus poorly managed banks. We report the results using the balance sheet loan loss measure to retain the largest number of observations. Results for the flow measure are somewhat weaker. Similar to the results reported in Table 5 we find that banks with greater delays in expected loss recognition lend less during recessions and are more capital constrained during recessions than banks with smaller delays. This result holds across both well versus poorly managed partitions. In addition, consistent with what would be expected, we find the extent to which banks with greater delays are capital constrained during recessions is greater for poorly managed banks than for well managed banks. For the well managed banks we find no 
significant difference for smaller versus greater delay banks in average lending or in the sensitivity of lending to regulatory capital in non-recessionary periods. This suggests that our delay measure is not merely capturing other differences in these banks.

The results of our analysis of the change in pre-provision equity are reported in Table 7. Consistent with H5, we find that banks with smaller delays have an incremental increase in preprovision equity in the expansionary periods. This result is consistent with smaller delay banks taking actions to build-up capital, thereby alleviating the capital adequacy concerns that arise from larger current provisions, during expansions when these actions are relatively cheap. These actions increase smaller delay banks regulatory capital, thereby mitigating recessionary lending cuts. We find this result holds across our management quality partitions, although the effect is stronger for poorly managed banks. For poorly managed banks, during expansionary periods, smaller delay banks have a $22 \%$ greater increase in capital than greater delay banks. Further, we see a relative decline in the increases in pre-provision equity during recessions for all banks, but this decline is significantly lower for smaller delay banks. This result also holds across our management quality partitions, although the result is statistically stronger for well managed banks. These results are consistent with the cost of raising equity being higher during recessions, and with smaller delay banks raising more equity during non-recessionary periods to compensate for higher provisioning. Our results are also consistent with a smaller increase in the cost of raising equity during recessions for smaller delay banks.

\subsection{Robustness checks}

We perform several robustness checks to assess the sensitivity of our results to our research design choices. First, as an alternative proxy for recessions, we use a measure based on the change in the Federal Funds Rate. Specifically, we define a period to be a recessionary period 
if there is a $-0.75 \%$ or more negative change in the federal funds rate during the quarter. The correlation of this variable with the NBER recession variable is $73 \%$ and our results are unchanged using this alternative measure. Second, we include several other macro control variables in addition to $\triangle U N R A T E$. Specifically, we include quarterly changes in personal consumption expenditures, in compensation of employees' wages and salary accruals, in the industrial production index, and in GDP (all variables are obtained from the St. Louis Fed Economic Research database.) The correlations of these variables with $\triangle U N R A T E$ ranges from $57 \%$ to $-78 \%$. Including these variables does not change the results on the other variables included in the model. Third, we redefine our dependent variable as change in total loans scaled by lagged total assets, and the results continue to hold.

\section{Supplemental analyses}

\subsection{Comparison of Basel period to period without capital regulation}

Our results suggest that during the Basel period banks with assets greater than $\$ 500$ million that have greater delays in expected loss recognition suffer from a capital crunch during recessions. If so, then we would not expect to see a similar effect during the period prior to the implementation of numerical regulatory capital requirements. We therefore compare coefficients from our 4 Loans model for the period prior to capital regulation to the post-Basel period. Specifically, we compare estimates from the 1961:1 to 1981:4 period to the 1993:4-2009:2 period. During the pre-regulatory period the NBER declared recessions during 1970:1-3, 1974:1 - 1975:1 and 1980:1-2. Since Tier 1 capital ratios are unavailable during the earlier period we substitute a primary capital ratio for the Tier 1 capital ratio in our $\Delta$ Loans model. We estimate the primary ratio as the sum of common equity (COMPUSTAT "ceqq") plus nonredeemable preferred stock (COMPUSTAT “pstkq") minus goodwill (COMPUSTAT data "gdwlq"), scaled 
by total assets (COMPUSTATA data "atq"). The correlation between this variable and the Tier 1 capital ratio during the Basel period is 55\%. In Table 8 we report the results of repeating our capital crunch tests using this alternative variable for both the pre-regulatory and Basel periods. Although we replicate the Basel capital crunch results using this alternative primary capital ratio we find no evidence of a capital crunch during the pre-regulatory period.

We also examine how the capital crunch differs for banks with smaller versus greater delays in expected loss recognition based on our market measure. Our results are similar during the post-Basel period using this alternative capital measure to those reported in Table 5, but we find no evidence of a capital crunch effect for greater delay banks during the pre-regulatory period. These findings corroborate our previous evidence that the current capital regulation and accounting rules give rise to pro-cyclicality.

\subsection{Predicting future and concurrent non-performing loans using current macro variables}

In our flow measure we use the actual future and concurrent nonperforming loans to capture predicted future and concurrent nonperforming loans, assuming that on average banks can accurately forecast future nonperforming loans. Table 9 provides the results of our sensitivity tests of this assumption in which we substitute predicted changes in future and concurrent nonperforming loans for actual changes in future and concurrent nonperforming loans. We predict the change in non-performing loans using the bank-level regression of $\triangle \mathrm{NPL}$ on concurrent and lagged changes in the unemployment rate and in the industrial production index published by FED. The results reported in Table 9 are similar although somewhat stronger than the results reported for our flow measure in Table 5. That is, we continue to find that smaller delay banks reduce their lending less than greater delay banks during recessionary periods and that smaller delay banks display a lower capital-lending sensitivity in recessions than greater 
delay banks. These results are consistent with smaller delay banks using current macroeconomic data to forecast future nonperforming loans. ${ }^{28}$

\section{Conclusion}

In response to the current financial crisis, the FSF (2009) issued a report recommending that regulators and policy makers reconsider the role of loan loss provisioning in the procyclicality of the financial system. Specifically they stated that

Earlier recognition of loan losses could have dampened cyclical moves in the current crisis, and that earlier identification of and provisioning for credit losses are consistent both with financial statement users' needs for transparency regarding changes in credit trends and with prudential objectives of safety and soundness.

We exploit cross-sectional variation in implementation of the incurred loss framework to investigate the effect of delay in recognizing expected loan losses on banks' lending behaviors. Our study sheds some light on whether delays in expected loss recognition contribute to the procyclicality of regulatory capital requirements. We find that during the period after implementation of Basel risk based capital regulations and FDICIA, banks with greater delays in expected loss recognition reduce their lending during recessions more than banks with smaller delays. We also find that banks with greater delays are more subject to capital crunches during recessions compared to smaller delay banks. Our study indicates that the lending of banks with smaller delays in expected loss recognition is less pro-cyclical. This holds across partitions of well managed and poorly managed banks.

We also find that banks with smaller delays increase their pre-provision equity more during non-recessionary periods and decrease their pre-provision equity less during recessions

\footnotetext{
${ }^{28} \mathrm{We}$ also tried only predicting the future non-performing loans using macro-variables with the original current nonperforming loans in calculating R-squared, and the results remain similar.
} 
than banks with greater delays. This provides smaller delay banks with the ability to reduce their lending less during recessions without increasing their regulatory capital adequacy concerns.

In supplemental tests, we find no evidence of pro-cyclicality related to the capital ratio in the period prior to capital regulation. Taken together, these results suggest that capital regulation combined with greater delays in recognizing expected losses leads to the capital crunch on lending during recessions.

Finally, we find that large banks are more vulnerable to capital constraints compared to small banks. This finding is in contrast to the results of studies conducted prior to the implementation of FDICIA. These findings suggest that the prompt corrective action and the internal control provisions of FDICIA may have had the unintended consequence of making bank lending more pro-cyclical. 


\section{References}

Ahmed, A., C. Takeda, and S. Thomas, 1999. Bank loan loss provisions: a re-examination of capital management, earnings management and signaling effects. Journal of Accounting and Economics 28, 1-25.

Altamuro, J., and A. Beatty, 2010. How does internal control regulation affect financial reporting. Journal of Accounting and Economics, 49, 58-74.

Angrist, J., and A. Krueger, 2001. Instrumental Variables and the Search for Identification: From Supply and Demand to Natural Experiments, Journal of Economic Perspectives 15, 69-85.

Basu, S., 1997. The conservatism principle and the asymmetric timeliness of earnings. Journal of Accounting Economics 24, 3-37.

Bernanke, B. and C. Lown, 1991. The credit crunch. Brookings Papers on Economic Activity 2, 205-247.

Bernanke, B., and M. Gertler, 1995. Inside the black box: the credit channel of monetary policy transmission. Journal of Economic Perspectives 9, 27-48.

Bernanke, B., M. Gertler, and S. Gilchrist, 1999. The financial accelerator in a quantitative business cycle framework. Handbook of Macroeconomics, Chapter 21, Taylor J and Woodford M (eds.) Amsterdam: Elsevier, 1341-1393

Bharath T., J. Sunder, and S. Sunder, 2008. Accounting quality and debt contracting. The Accounting Review 83, 1-28

Biddle, G., and G. Hilary, 2006. Accounting quality and firm-level capital investment. The Accounting Review 81, 963-982.

Bushman, R., and C. Williams, 2009. Accounting discretion, loan loss provisioning, and discipline of banks' risk-taking. Working Paper, UNC.

DeYoung, R., 1998. Management quality and X-efficiency in national banks. Journal of Financial Services Research, 13(1) 5-22.

Dugan, J., 2009. Loan loss provisioning and pro-cyclicality. Remarks by John C. Dugan Comptroller of the Currency before the Institute of International Bankers http://www.occ.treas.gov/ftp/release/2009-16a.pdf

Financial Stability Forum, 2009. Report of the financial stability forum on addressing procyclicality in the financial system. http://www.financialstabilityboard.org/publications/r_0904a.pdf 
Fitch, 2009. A universal spreadsheet for bank analysis. http://www.fitchratings.com/dtp/pdf209/bubt1404.pdf

Gambera, M., 2000. Simple forecasts of bank loan quality in the business cycle. Working Paper, Federal Reserve Bank of Chicago

Handorf, W., and L. Zhu, 2006. US bank loan-loss provisions, economic conditions, and regulatory guidance. Journal of Applied Finance April, 97-114

Hilary, G., 2008. Accounting quality and catastrophic market events. Working Paper, HKUST

Healy, P. and J. Wahlen, 1999. A review of the earnings management literature and its implications for standard settings. Accounting Horizons 13, 365-383

Ivashina V., and D. Scharfstein, 2010. Bank lending during the financial crisis of 2008. Journal of Financial Economics 97, 319-338.

Liu, C., and S. Ryan, 2006. Income smoothing over the business cycle: changes in banks' coordinated management of provisions for loan losses and loan charge-offs from the pre-1990 bust to the 1990s boom. The Accounting Review 81, 421-441.

Kashyap, A., and J. Stein, 2000. What do a million observations on banks say about the transmission of monetary policy? The American Economic Review 90, 407-428.

Khan, M. and R. Watts, 2009. Estimation and empirical properties of a firm-year measure of accounting conservatism. Journal of Accounting and Economics 48, 132-150

Kishan, R, and T. Opiela, 2000. Bank size, bank capital, and the bank lending channel. Journal of Money, Credit and Banking 32, 121-141

Kishan, R., and T. Opiela, 2006. Bank capital and loan asymmetry in the transmission of monetary policy. Journal of Banking and Finance 30, 259-285.

Myers, S., and N. Majluf, 1984. Corporate financing and investment decisions when firms have information that investors do not have. Journal of Financial Economics 13, 187-221.

Nichols, D., J. Wahlen, and M. Wieland, 2009. Publicly-traded versus privately-held: implications for bank profitability, growth risk, and accounting conservatism. Review of Accounting Studies 14, 88-122

Stein, J., 1998. An adverse selection model of bank asset and liability management with implications for the transmission of monetary policy. RAND Journal of Economics $29,466-486$ 
Van den Heuvel, S., 2009. The bank capital channel of monetary policy. Working Paper, Federal Reserve Board of Governors. 
Figure 1: Trend in the median of adjusted R-squared of provision prediction models using the sample of banks greater than \$500 Million, 1996Q1-2009Q2

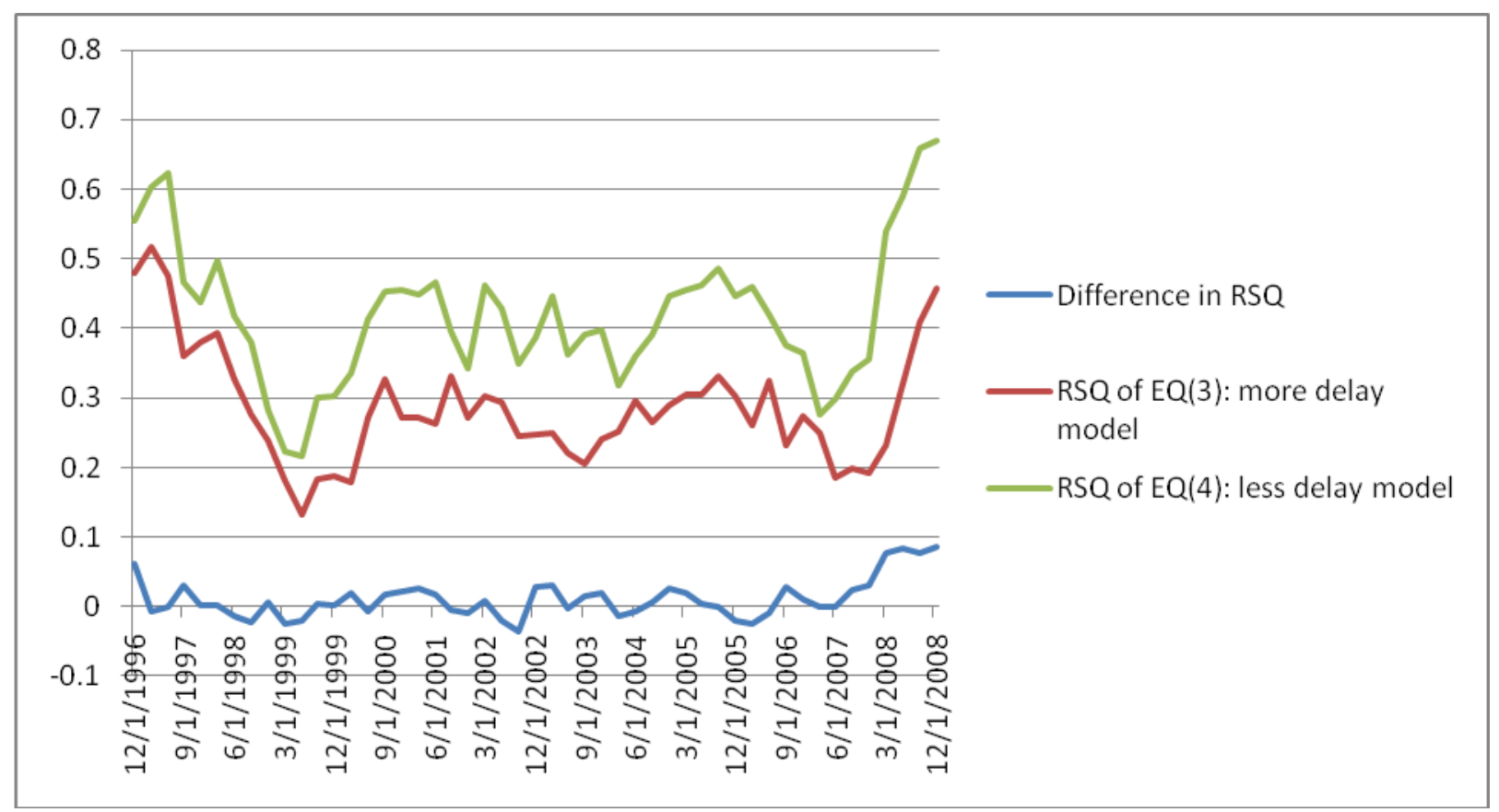

Panel B: Descriptive statistics of the bank-quarter flow measure of expected loss recognition

\begin{tabular}{|c|c|c|c|c|c|}
\hline & Mean & Median & Q1 & Q3 & $\begin{array}{c}\text { Standard } \\
\text { Deviation }\end{array}$ \\
\hline $\begin{array}{c}\text { Adj RSQ for EQ(3): } \\
\text { More Delay Model }\end{array}$ & 0.257 & 0.274 & -0.037 & 0.556 & 0.372 \\
\hline $\begin{array}{c}\text { Adj RSQ for EQ(4): } \\
\text { Less Delay Model }\end{array}$ & 0.325 & 0.412 & 0.037 & 0.690 & 0.448 \\
\hline $\begin{array}{c}\text { Difference in adj } \\
\text { RSQ }\end{array}$ & 0.068 & 0.012 & -0.119 & 0.199 & 0.303 \\
\hline
\end{tabular}


Table 1: Bank characteristics (means) by recession vs. expansion 1993Q3- 2009Q2

\begin{tabular}{|c|c|c|}
\hline & $\begin{array}{c}\text { Recession Periods } \\
\text { (2001Q2:2001Q4 and 2008Q1:2009Q2) }\end{array}$ & Expansion Periods \\
\hline Variables & Mean & $\begin{array}{c}\text { Mean } \\
\text { (t-stat for differences) }\end{array}$ \\
\hline$\Delta$ Loan & 0.0168 & $\begin{array}{c}0.0276 \\
(-13.84)^{* * *} \\
\end{array}$ \\
\hline Capital R1 & 0.1069 & $\begin{array}{c}0.1113 \\
(-6.15)^{* * * *} \\
\end{array}$ \\
\hline Provision & 0.0024 & $\begin{array}{c}0.0009 \\
(26.75)^{* * *}\end{array}$ \\
\hline$\Delta \mathrm{NPL}$ & 0.0003 & $\begin{array}{c}-0.0000 \\
(12.43)^{* * *}\end{array}$ \\
\hline EBP & 0.0051 & $\begin{array}{c}0.0073 \\
(-23.94)^{* * *}\end{array}$ \\
\hline Size & 7.3414 & $\begin{array}{c}7.1487 \\
(5.94) * * *\end{array}$ \\
\hline Deposits & 1.1180 & $\begin{array}{c}1.2568 \\
(-18.12)^{* * *}\end{array}$ \\
\hline$\triangle$ UNRATE & 0.4666 & $\begin{array}{c}-0.0630 \\
(162.45)^{* * *}\end{array}$ \\
\hline$\Delta$ Capital R1 & -0.0012 & $\begin{array}{c}-0.0006 \\
(3.35) * * *\end{array}$ \\
\hline$\sigma_{\text {ret }}$ & 0.0301 & $\begin{array}{c}0.0214 \\
(39.14)^{* * *}\end{array}$ \\
\hline $\mathrm{N}$ of bank-quarters & 2,763 & 22,025 \\
\hline
\end{tabular}

$* * *, * *$, and * represent $1 \%, 5 \%$, and $10 \%$ significance, respectively.

Variable Definition:

$\triangle$ Loan: $\quad$ Change in the natural log of loans (COMPUSTAT "Intalq").

Capital R1: Tier I risk-adjusted capital ratio (COMPUSTAT "capr1q") at the beginning of the quarter, divided by 100 .

Provision : $\quad$ Loan loss provision (COMPUSTAT “pllq”) divided by lagged total loans (COMPUSTAT "Intalq").

$\triangle N P L: \quad C h a n g e$ in non-performing assets (COMPUSTAT "npatq") divided by lagged total loans (COMPUSTAT "Intalq").

EBP: $\quad$ Earnings before provision, defined as (COMPUSTAT "piq" + data "pllq") scaled by lagged total loans (COMPUSTAT "Intalq").

Size: $\quad$ The natural log of total assets (COMPUSTAT "atq") at the beginning of the quarter.

Deposits: Total deposits (COMPUSTAT “dptcq) divided by total loans, at the beginning of the quarter.

$\triangle$ UNRATE: The change in the quarterly unemployment rate.

$\Delta$ Capital R1: Change in variable Capital Rl, beginning tier I capital ratio subtract lagged beginning tier I capital ratio. 
$\sigma_{r e t}: \quad$ Standard deviation of daily return of the previous quarter. 
Table 2: Pearson correlation analysis (p-values in the parentheses), 1993Q3-2009Q2

\begin{tabular}{|c|c|c|c|c|c|c|c|c|c|}
\hline Variables & Capital R1 & Prov & $\Delta \mathrm{NPL}$ & EBP & Size & Deposits & $\Delta$ UNRATE & $\Delta$ Capital R1 & $\sigma_{r e t}$ \\
\hline$\Delta$ Loan & $\begin{array}{c}0.068 \\
(0.001)\end{array}$ & $\begin{array}{c}-0.079 \\
(0.001)\end{array}$ & $\begin{array}{c}0.004 \\
(0.581)\end{array}$ & $\begin{array}{c}0.083 \\
(0.001)\end{array}$ & $\begin{array}{c}-0.068 \\
(0.001)\end{array}$ & $\begin{array}{c}0.054 \\
(0.001)\end{array}$ & $\begin{array}{l}-0.126 \\
(0.001)\end{array}$ & $\begin{array}{l}-0.047 \\
(0.001)\end{array}$ & $\begin{array}{l}-0.036 \\
(0.001)\end{array}$ \\
\hline Capital R1 & & $\begin{array}{c}-0.067 \\
(0.001)\end{array}$ & $\begin{array}{l}-0.006 \\
(0.340)\end{array}$ & $\begin{array}{c}0.210 \\
(0.001)\end{array}$ & $\begin{array}{c}-0.218 \\
(0.001)\end{array}$ & $\begin{array}{c}0.265 \\
(0.001)\end{array}$ & $\begin{array}{l}-0.030 \\
(0.001)\end{array}$ & $\begin{array}{c}0.071 \\
(0.001)\end{array}$ & $\begin{array}{l}-0.058 \\
(0.001)\end{array}$ \\
\hline Provision & & & $\begin{array}{c}0.060 \\
(0.001)\end{array}$ & $\begin{array}{c}-0.015 \\
(0.019)\end{array}$ & $\begin{array}{c}0.098 \\
(0.001)\end{array}$ & $\begin{array}{c}-0.019 \\
(0.002)\end{array}$ & $\begin{array}{c}0.164 \\
(0.001)\end{array}$ & $\begin{array}{c}-0.003 \\
(0.667)\end{array}$ & $\begin{array}{c}0.171 \\
(0.001)\end{array}$ \\
\hline$\Delta \mathrm{NPL}$ & & & & $\begin{array}{c}-0.101 \\
(0.001)\end{array}$ & $\begin{array}{c}-0.001 \\
(0.809)\end{array}$ & $\begin{array}{c}-0.010 \\
(0.140)\end{array}$ & $\begin{array}{c}0.094 \\
(0.001)\end{array}$ & $\begin{array}{l}-0.031 \\
(0.001)\end{array}$ & $\begin{array}{c}0.058 \\
(0.001)\end{array}$ \\
\hline EBP & & & & & $\begin{array}{c}0.305 \\
(0.001)\end{array}$ & $\begin{array}{c}0.373 \\
(0.001)\end{array}$ & $\begin{array}{l}-0.144 \\
(0.001)\end{array}$ & $\begin{array}{c}0.037 \\
(0.001)\end{array}$ & $\begin{array}{l}-0.226 \\
(0.001)\end{array}$ \\
\hline Size & & & & & & $\begin{array}{c}-0.073 \\
(0.001)\end{array}$ & $\begin{array}{c}0.044 \\
(0.001)\end{array}$ & $\begin{array}{c}0.023 \\
(0.001)\end{array}$ & $\begin{array}{l}-0.368 \\
(0.001)\end{array}$ \\
\hline Deposits & & & & & & & $\begin{array}{c}-0.138 \\
(0.001)\end{array}$ & $\begin{array}{c}0.018 \\
(0.005)\end{array}$ & $\begin{array}{c}0.037 \\
(0.001)\end{array}$ \\
\hline$\triangle$ UNRATE & & & & & & & & $\begin{array}{l}-0.022 \\
(0.001)\end{array}$ & $\begin{array}{c}0.209 \\
(0.001) \\
\end{array}$ \\
\hline$\Delta$ Capital R1 & & & & & & & & & $\begin{array}{l}-0.012 \\
(0.062)\end{array}$ \\
\hline
\end{tabular}

Variable Definition:

$\triangle$ Loan: Change in the natural log of loans (COMPUSTAT "Intalq").

Capital R1: Tier I risk-adjusted capital ratio (COMPUSTAT "capr1q") at the beginning of the quarter, divided by 100.

Provision : Loan loss provision (COMPUSTAT "pllq") divided by lagged total loans (COMPUSTAT "Intalq").

$\triangle \mathrm{NPL}: \quad$ Change in non-performing assets (COMPUSTAT "npatq") divided by lagged total loans (COMPUSTAT "Intalq").

EBP: $\quad$ Earnings before provision, (COMPUSTAT "piq" + data "pllq") scaled by lagged total loans (COMPUSTAT "Intalq").

Size: $\quad$ The natural log of total assets (COMPUSTAT "atq") at the beginning of the quarter.

Deposits: Total deposits (COMPUSTAT “dptcq) divided by total loans, at the beginning of the quarter.

$\triangle$ UNRATE: The change in the quarterly unemployment rate.

$\Delta$ Capital R1: Change in variable Capital R1, beginning tier I capital ratio subtract lagged beginning tier I capital ratio.

$\sigma_{\text {ret }}$ : $\quad$ Standard deviation of daily return of the previous quarter. 
Table 3: Analysis of the effects of capital ratio and recession on change in loans

Panel A: Overall sample and subsamples using $\$ 500$ million as the cutoff point

\begin{tabular}{|c|c|c|c|c|}
\hline & & Overall Sample & $\begin{array}{c}\text { Bank Size } \\
<500 \mathrm{M}\end{array}$ & Bank Size $>500 M$ \\
\hline & Prediction & $\begin{array}{c}\text { Coefficients } \\
\text { (clustered t-stat) }\end{array}$ & $\begin{array}{c}\text { Coefficients } \\
\text { (clustered t-stat) }\end{array}$ & $\begin{array}{c}\text { Coefficients } \\
\text { (clustered t-stat) }\end{array}$ \\
\hline Intercept & $+/-$ & $\begin{array}{c}0.032 \\
(9.70) * * *\end{array}$ & $\begin{array}{c}0.018 \\
(2.46)^{* *}\end{array}$ & $\begin{array}{c}0.037 \\
(8.34) * * *\end{array}$ \\
\hline Recession & - & $\begin{array}{c}-0.006 \\
(-1.45)^{*}\end{array}$ & $\begin{array}{l}0.004 \\
(0.48)\end{array}$ & $\begin{array}{c}-0.013 \\
(-2.88) * * *\end{array}$ \\
\hline Capital R1 & + & $\begin{array}{c}0.044 \\
(3.73)^{* * * *}\end{array}$ & $\begin{array}{c}0.075 \\
(4.49)^{* * *}\end{array}$ & $\begin{array}{c}0.020 \\
(1.62)^{*}\end{array}$ \\
\hline $\begin{array}{l}\text { Recession *Capital } \\
\text { R1 }\end{array}$ & + & $\begin{array}{c}0.068 \\
(2.26)^{* *}\end{array}$ & $\begin{array}{l}-0.037 \\
(-0.73)\end{array}$ & $\begin{array}{c}0.138 \\
(4.29) * * *\end{array}$ \\
\hline$\triangle$ UNRATE & - & $\begin{array}{c}-0.019 \\
(-4.84) * * *\end{array}$ & $\begin{array}{c}-0.021 \\
(-3.73)^{* * *}\end{array}$ & $\begin{array}{c}-0.019 \\
(-4.54) * * *\end{array}$ \\
\hline Size & $+/-$ & $\begin{array}{c}-0.002 \\
(-5.75)^{* * *}\end{array}$ & $\begin{array}{l}-0.000 \\
(-0.11)\end{array}$ & $\begin{array}{c}-0.002 \\
(-5.62)^{* * *}\end{array}$ \\
\hline Deposits & + & $\begin{array}{c}0.003 \\
(2.03)^{* *}\end{array}$ & $\begin{array}{c}0.003 \\
(1.95)^{* *}\end{array}$ & $\begin{array}{c}0.003 \\
(1.86)^{* *}\end{array}$ \\
\hline$\Delta$ Capital R1 & $+/-$ & $\begin{array}{c}-0.214 \\
(-6.46)^{* * *}\end{array}$ & $\begin{array}{c}-0.389 \\
(-6.69) * * *\end{array}$ & $\begin{array}{c}-0.107 \\
(-2.80)^{* * *}\end{array}$ \\
\hline$\sigma_{\text {ret }}$ & $+/-$ & $\begin{array}{c}-0.128 \\
(-2.08) * *\end{array}$ & $\begin{array}{c}-0.098 \\
(-1.67)^{*}\end{array}$ & $\begin{array}{l}-0.130 \\
(-1.59)\end{array}$ \\
\hline R-Squared & & 0.0261 & 0.0304 & 0.0248 \\
\hline $\mathrm{N}$ & & 24,788 & 7,404 & 17,384 \\
\hline \multicolumn{3}{|c|}{$\begin{array}{l}\text { Test of Equality of Coefficient on Recession } * \text { Capital } \\
R 1 \text { (between large and small banks) }\end{array}$} & \multicolumn{2}{|c|}{$\chi^{2}(1)=16.81 \mathrm{p}$-value $=0.001$} \\
\hline
\end{tabular}

$* * *, * *$, and $*$ represent $1 \%, 5 \%$ and $10 \%$ significance (two-tailed or one-tailed, as appropriate), respectively. 
Panel B: $\$ 300$ million, $\$ 500$ million and $\$ 1$ billion as the cutoff points

\begin{tabular}{|c|c|c|c|c|c|}
\hline & & $\begin{array}{c}\text { Bank Size } \\
<300 \mathrm{M}\end{array}$ & $\begin{array}{c}300 \mathrm{M}<=\text { Bank } \\
\text { Size }<500 \mathrm{M}\end{array}$ & $\begin{array}{c}500 \mathrm{M}<=\text { Bank } \\
\text { Size }<1 \mathrm{~B}\end{array}$ & Bank Size >1B \\
\hline & Pred & $\begin{array}{c}\text { Coefficients } \\
\text { (clustered t-stat) }\end{array}$ & $\begin{array}{c}\text { Coefficients } \\
\text { (clustered t-stat) }\end{array}$ & $\begin{array}{c}\text { Coefficients } \\
\text { (clustered t-stat) }\end{array}$ & $\begin{array}{c}\text { Coefficients } \\
\text { (clustered t-stat) }\end{array}$ \\
\hline Intercept & $+/-$ & $\begin{array}{c}0.022 \\
(2.21)^{* *}\end{array}$ & $\begin{array}{c}0.215 \\
(7.25)^{* * * *}\end{array}$ & $\begin{array}{c}0.154 \\
(7.91)^{* * * *}\end{array}$ & $\begin{array}{c}0.041 \\
(7.37)^{* * * *}\end{array}$ \\
\hline Recession & - & $\begin{array}{l}-0.007 \\
(-0.85)\end{array}$ & $\begin{array}{c}0.017 \\
(1.80)^{*}\end{array}$ & $\begin{array}{l}-0.006 \\
(-1.37)\end{array}$ & $\begin{array}{c}-0.014 \\
(-2.83) * * *\end{array}$ \\
\hline Capital R1 & + & $\begin{array}{c}0.110 \\
(5.42)^{* * * *}\end{array}$ & $\begin{array}{l}0.012 \\
(0.57)\end{array}$ & $\begin{array}{l}0.018 \\
(1.18)\end{array}$ & $\begin{array}{l}0.015 \\
(0.99)\end{array}$ \\
\hline $\begin{array}{l}\text { Capital } \\
\text { R1*Recession }\end{array}$ & + & $\begin{array}{c}0.029 \\
(0.029)\end{array}$ & $\begin{array}{l}-0.116 \\
(-1.76)^{*}\end{array}$ & $\begin{array}{c}0.112 \\
(3.77)^{* * * *}\end{array}$ & $\begin{array}{c}0.138 \\
(3.56)^{* * * *}\end{array}$ \\
\hline$\triangle \Delta$ UNRATE & - & $\begin{array}{c}-0.020 \\
(-3.10) * * *\end{array}$ & $\begin{array}{c}-0.021 \\
(-3.74) * * *\end{array}$ & $\begin{array}{c}-0.023 \\
(-5.11)^{* * *}\end{array}$ & $\begin{array}{c}-0.017 \\
(-3.75) * * *\end{array}$ \\
\hline Size & $+/-$ & $\begin{array}{l}-0.001 \\
(-0.69)\end{array}$ & $\begin{array}{c}-0.033 \\
(-6.76) * * *\end{array}$ & $\begin{array}{c}-0.020 \\
(-6.78) * * *\end{array}$ & $\begin{array}{c}-0.002 \\
(-5.52) * * *\end{array}$ \\
\hline Deposits & + & $\begin{array}{l}0.001 \\
(0.52)\end{array}$ & $\begin{array}{c}0.008 \\
(2.63)^{* * * *}\end{array}$ & $\begin{array}{l}0.000 \\
(0.04)\end{array}$ & $\begin{array}{c}0.004 \\
(2.32)^{* *}\end{array}$ \\
\hline$\Delta$ Capital R1 & $+/-$ & $\begin{array}{c}-0.512 \\
(-6.09) * * *\end{array}$ & $\begin{array}{c}-0.213 \\
(-2.54)^{* * *}\end{array}$ & $\begin{array}{c}-0.142 \\
(-2.17)^{* *}\end{array}$ & $\begin{array}{l}-0.080 \\
(-1.58)\end{array}$ \\
\hline$\overline{\sigma_{\text {ret }}}$ & $+/-$ & $\begin{array}{l}-0.111 \\
(-1.54)\end{array}$ & $\begin{array}{l}-0.069 \\
(-0.84)\end{array}$ & $\begin{array}{l}-0.068 \\
(-0.73)\end{array}$ & $\begin{array}{c}-0.178 \\
(-2.00) * *\end{array}$ \\
\hline R-Squared & & 0.0450 & 0.0386 & 0.0301 & 0.0276 \\
\hline $\mathrm{N}$ & & 3,937 & 3,467 & 5,302 & 12,082 \\
\hline
\end{tabular}

***,**, and * represent $1 \%, 5 \%$ and $10 \%$ significance (two-tailed or one-tailed, as appropriate), respectively.

Variable Definition:

$\Delta$ Loan: $\quad$ Change in the natural log of loans (COMPUSTAT "Intalq").

Recession: An indicator variable equal to one for periods between 2001Q2 and 2001Q4, and periods between 2008Q1 and 2009Q2; zero, otherwise.

$\Delta$ Loan: $\quad$ Change in the natural log of loans (COMPUSTAT "Intalq").

Capital R1: Tier I risk-adjusted capital ratio (COMPUSTAT "capr1q") at the beginning of the quarter, divided by 100 .

Size: $\quad$ The natural log of total assets (COMPUSTAT "atq") at the beginning of the quarter

Deposits: Total deposits (COMPUSTAT "dptcq) divided by total loans, at the beginning of the quarter.

$\triangle$ UNRATE: The change in the quarterly unemployment rate.

$\triangle$ Capital R1: Change in Capital R1, beginning tier I capital ratio subtract lagged beginning tier I capital ratio.

$\sigma_{r e t}: \quad$ Standard deviation of daily return of the previous quarter. 
Table 4: Properties of measures of delay in expected loss recognition

Panel A: Correlations ( $p$-values) between macroeconomic variables and changes in nonperforming loans

\begin{tabular}{|c|c|c|c|c|c|c|}
\hline & $\Delta \mathrm{NPL}_{\mathrm{t}}$ & $\Delta \mathrm{NPL}_{\mathrm{t}+1}$ & $\Delta$ UNRATE $_{\mathrm{t}}$ & $\Delta$ UNRATE $_{t-}$ & $\Delta \mathrm{IP}_{\mathrm{t}}$ & $\Delta \mathrm{IP}_{\mathrm{t}-1}$ \\
\hline$\Delta \mathrm{NPL}_{\mathrm{t}}$ & 1.000 & $\begin{array}{c}-0.160 \\
(0.001)\end{array}$ & $\begin{array}{c}0.148 \\
(0.001)\end{array}$ & $\begin{array}{c}0.125 \\
(0.001)\end{array}$ & $\begin{array}{c}-0.143 \\
(0.001)\end{array}$ & $\begin{array}{c}-0.107 \\
(0.001)\end{array}$ \\
\hline$\Delta \mathrm{NPL}_{\mathrm{t}+1}$ & & 1.000 & $\begin{array}{c}0.125 \\
(0.001)\end{array}$ & $\begin{array}{c}0.089 \\
(0.001)\end{array}$ & $\begin{array}{c}-0.107 \\
(0.001)\end{array}$ & $\begin{array}{c}-0.082 \\
(0.001)\end{array}$ \\
\hline$\Delta$ UNRATE $_{\mathrm{t}}$ & & & 1.000 & $\begin{array}{c}0.643 \\
(0.001) \\
\end{array}$ & $\begin{array}{c}-0.815 \\
(0.001)\end{array}$ & $\begin{array}{c}-0.728 \\
(0.001)\end{array}$ \\
\hline$\Delta$ UNRATE $_{\mathrm{t}-1}$ & & & & 1.000 & $\begin{array}{c}-0.579 \\
(0.001)\end{array}$ & $\begin{array}{c}-0.757 \\
(0.001)\end{array}$ \\
\hline$\Delta \mathrm{IP}_{\mathrm{t}}$ & & & & & 1.000 & $\begin{array}{c}0.756 \\
(0.001)\end{array}$ \\
\hline$\Delta \mathrm{IP}_{\mathrm{t}-1}$ & & & & & & 1.000 \\
\hline
\end{tabular}

Panel B: Associations between stock and market delay measures (in the form of dummies) and concurrent and one quarter ahead changes in non-performing loans

\begin{tabular}{|c|c|c|}
\hline & $\begin{array}{c}\text { Stock (Balance Sheet) } \\
\text { Measure }\end{array}$ & Market Measure \\
\hline Variables & $\begin{array}{c}\text { Coefficients } \\
\text { (z-stats) }\end{array}$ & $\begin{array}{c}\text { Coefficients } \\
\text { (z-stats) }\end{array}$ \\
\hline Intercept & $\begin{array}{c}-1.409 \\
(-14.61)^{* * * *}\end{array}$ & $\begin{array}{c}1.278 \\
(12.27)^{* * *}\end{array}$ \\
\hline$\Delta \mathrm{NPL}_{\mathrm{t}}$ & $\begin{array}{c}4.001 \\
(3.03)^{* * *}\end{array}$ & $\begin{array}{c}6.951 \\
(2.01)^{* *}\end{array}$ \\
\hline$\Delta \mathrm{NPL}_{\mathrm{t}+1}$ & $\begin{array}{c}1.519 \\
(1.76)^{*}\end{array}$ & $\begin{array}{l}-0.094 \\
(-0.03)\end{array}$ \\
\hline Capital R1 & $\begin{array}{c}5.043 \\
(13.47) * * *\end{array}$ & $\begin{array}{l}-0.597 \\
(-0.45)\end{array}$ \\
\hline$\triangle$ UNRATE & $\begin{array}{c}0.240 \\
(5.09) * * *\end{array}$ & $\begin{array}{c}-0.155 \\
(-2.86)^{* * *}\end{array}$ \\
\hline Size & $\begin{array}{c}0.113 \\
(14.22) * * *\end{array}$ & $\begin{array}{c}-0.171 \\
(-19.36)^{* * *}\end{array}$ \\
\hline Deposits & $\begin{array}{c}0.221 \\
(6.60)^{* * *}\end{array}$ & $\begin{array}{l}-0.030 \\
(-0.86)\end{array}$ \\
\hline$\Delta$ Capital R1 & $\begin{array}{c}-4.972 \\
(-3.88) * * *\end{array}$ & $\begin{array}{l}0.069 \\
(0.04)\end{array}$ \\
\hline$\sigma_{\text {ret }}$ & $\begin{array}{c}-14.836 \\
(-11.50)^{* * *}\end{array}$ & $\begin{array}{c}8.775 \\
(6.58)^{* * * *}\end{array}$ \\
\hline $\mathrm{N}$ & 15,216 & 12,202 \\
\hline Pseudo-Rsquared & 0.0348 & 0.0223 \\
\hline
\end{tabular}


$* * *, * *$, and $*$ represent $1 \%, 5 \%$, and $10 \%$ significance, respectively.

Variable Definition:

SNPL: $\quad$ Change in non-performing assets (COMPUSTAT "npatq") divided by lagged total loans (COMPUSTAT "Intalq").

$\triangle$ UNRATE: Change in the quarterly unemployment rate.

$\Delta \mathrm{IP}: \quad$ Change in the quarterly industry production rate.

$<$ Delay (Stock Measure): An indicator variable equal to one if the lagged ALWN is greater than the median during the quarter, and zero otherwise. ALWN is defined as loan loss allowance (COMPUSTAT "rclq") divided by non-performing assets (COMPUSTAT "npatq").

$<$ Delay (Market Measure): An indicator variable equal to one if the lagged CSCORE is greater than the median during the quarter, and zero otherwise. CSCORE is calculated using Khan and Watts' (2009) technique to measure bank-quarter conservatism.

Capital R1: Tier I risk-adjusted capital ratio (COMPUSTAT "capr1q") at the beginning of the quarter, divided by 100 .

Size: the natural log of total assets (COMPUSTAT "atq") at the beginning of the quarter.

Deposits: $\quad$ total deposits (COMPUSTAT “dptcq) divided by total loans, at the beginning of the quarter.

$\Delta$ Capital R1: Change in variable Capital $R 1$, beginning tier I capital ratio subtract lagged beginning tier I capital ratio.

$\sigma_{\text {ret }}: \quad$ Standard deviation of daily return of the previous quarter. 
Table 5: Analysis of the effects of capital ratio, recession, and delay in loss recognition on change in loans for banks with assets $>\$ 500$ million.

\begin{tabular}{|c|c|c|c|c|}
\hline & & Flow Measure & Stock Measure & Market Measure \\
\hline Variables & Prediction & $\begin{array}{c}\text { Coefficients } \\
\text { (clustered t- } \\
\text { stats) }\end{array}$ & $\begin{array}{c}\text { Coefficients } \\
\text { (clustered t- } \\
\text { stats) }\end{array}$ & $\begin{array}{c}\text { Coefficients } \\
\text { (clustered t- } \\
\text { stats) }\end{array}$ \\
\hline Intercept & $+/-$ & $\begin{array}{c}0.033 \\
(6.67)^{* * *} \\
\end{array}$ & $\begin{array}{c}0.037 \\
(8.58)^{* * *}\end{array}$ & $\begin{array}{c}0.034 \\
(7.13)^{* * *}\end{array}$ \\
\hline$<$ Delay & $+/-$ & $\begin{array}{l}0.004 \\
(0.84)\end{array}$ & $\begin{array}{l}-0.001 \\
(-0.42)\end{array}$ & $\begin{array}{l}-0.002 \\
(-0.69)\end{array}$ \\
\hline Recession & - & $\begin{array}{c}-0.021 \\
(-2.70)^{* * *}\end{array}$ & $\begin{array}{c}-0.031 \\
(-5.36) * * *\end{array}$ & $\begin{array}{c}-0.017 \\
(-2.71)^{* * *}\end{array}$ \\
\hline Recession $*<$ Delay & + & $\begin{array}{c}0.016 \\
(1.81)^{* *}\end{array}$ & $\begin{array}{c}0.037 \\
(8.29)^{* * *} \\
\end{array}$ & $\begin{array}{c}0.011 \\
(1.86)^{* *}\end{array}$ \\
\hline Capital R1 & + & $\begin{array}{l}0.020 \\
(0.69)\end{array}$ & $\begin{array}{l}-0.012 \\
(-0.74)\end{array}$ & $\begin{array}{l}0.011 \\
(0.54)\end{array}$ \\
\hline Capital R1 $*<$ Delay & $+/-$ & $\begin{array}{l}-0.047 \\
(-1.29)\end{array}$ & $\begin{array}{c}0.048 \\
(2.23)^{* *}\end{array}$ & $\begin{array}{l}0.007 \\
(0.24)\end{array}$ \\
\hline Capital R1* Recession & + & $\begin{array}{c}0.214 \\
(3.44)^{* * *}\end{array}$ & $\begin{array}{c}0.278 \\
(5.78)^{* * *}\end{array}$ & $\begin{array}{c}0.221 \\
(4.85)^{* * *}\end{array}$ \\
\hline $\begin{array}{l}\text { Capital R1* Recession } \\
*<\text { Delay }\end{array}$ & - & $\begin{array}{c}-0.138 \\
(-1.75)^{* *} \\
\end{array}$ & $\begin{array}{c}-0.279 \\
(-6.34) * * * \\
\end{array}$ & $\begin{array}{c}-0.182 \\
(-3.34)^{* * *} \\
\end{array}$ \\
\hline$\triangle \mathrm{UNRATE}$ & - & $\begin{array}{c}-0.017 \\
(-3.69) * * *\end{array}$ & $\begin{array}{c}-0.019 \\
(-4.64) * * *\end{array}$ & $\begin{array}{c}-0.018 \\
(-3.92)^{* * *}\end{array}$ \\
\hline Size & $+/-$ & $\begin{array}{c}-0.001 \\
(-3.72)^{* * *}\end{array}$ & $\begin{array}{c}-0.002 \\
(-5.60) * * *\end{array}$ & $\begin{array}{c}-0.001 \\
(-4.63)^{* * *}\end{array}$ \\
\hline Deposits & + & $\begin{array}{l}0.001 \\
(0.64)\end{array}$ & $\begin{array}{l}-0.001 \\
(1.00)\end{array}$ & $\begin{array}{c}0.003 \\
(1.95)^{* *}\end{array}$ \\
\hline$\Delta$ Capital R1 & $+/-$ & $\begin{array}{l}-0.060 \\
(-0.94)\end{array}$ & $\begin{array}{c}-0.128 \\
(-3.09) * * *\end{array}$ & $\begin{array}{c}-0.276 \\
(-5.04)^{* * *}\end{array}$ \\
\hline$\sigma_{\text {ret }}$ & $+/-$ & $\begin{array}{l}-0.160 \\
(-1.61)\end{array}$ & $\begin{array}{c}-0.128 \\
(-1.68) *\end{array}$ & $\begin{array}{c}-0.123 \\
(-1.83)^{*}\end{array}$ \\
\hline R-Squared & & 0.0254 & 0.0318 & 0.0288 \\
\hline $\mathrm{N}$ & & 8,128 & 15,971 & 13,413 \\
\hline
\end{tabular}

$* * *, * *, \& *$ represent $1 \%, 5 \% \& 10 \%$ significance, respectively (two-tailed or one-tailed, as appropriate).

Variable Definition:

$\Delta$ Loan: Change in the natural log of loans (COMPUSTAT "Intalq").

$<$ Delay:

(Flow Measure): An indicator variable equal to one if the lagged delay measure is greater than the median during the quarter, where the delay measure is the difference in adjusted R-squared (EQ2-EQ1) from the following two rolling regressions 
for each bank-quarter using the observations of the past 3 years. We require 12 observations in each regression.

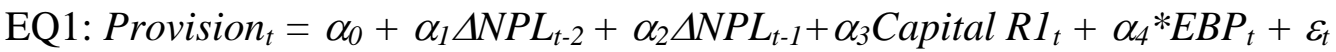

$$
\begin{aligned}
& \text { EQ2: } \text { Provision }_{t}=\alpha_{0}+\alpha_{1} \Delta N P L_{t-2}+\alpha_{2} \Delta N P L_{t-1}+\alpha_{3} \Delta N P L_{t}+\alpha_{4} \Delta N P L_{t+1} \\
& +\alpha_{5} \text { Capital RI } 1_{t}+\alpha_{6} E B P_{t}+\varepsilon_{t}
\end{aligned}
$$

Where

<Delay:

Provision = Loan loss provision (COMPUSTAT "pllq") divided by lagged total loans (COMPUSTAT "Intalq");

$\triangle \mathrm{NPL}=$ Change in non-performing assets (COMPUSTAT "npatq") divided by lagged total loans (COMPUSTAT "Intalq");

EBP = Earnings before loan loss provision, defined as (COMPUTAT "piq" plus COMPUSTAT “pllq", scaled by lagged COMPUSTAT "Intalq").

(Stock Measure): An indicator variable equal to one if the lagged ALWN is greater than the median during the quarter, and zero otherwise. ALWN is defined as loan loss allowance (COMPUSTAT "rclq") divided by non-performing assets (COMPUSTAT “npatq”).

$<$ Delay:

(Market Measure):An indicator variable equal to one if the lagged CSCORE is greater than the median during the quarter, and zero otherwise. CSCORE is calculated using Khan and Watts' (2009) technique to measure bank-quarter conservatism.

Recession: An indicator variable equal to one for periods between 2001Q2 and 2001Q4, and periods between 2008Q1 and 2009Q2; zero, otherwise.

Capital R1: Tier I risk-adjusted capital ratio (COMPUSTAT "capr1q") at the beginning of the quarter, divided by 100 .

$\triangle$ UNRATE: The change in the quarterly unemployment rate.

Size: $\quad$ The natural log of total assets (COMPUSTAT "atq") at the beginning of the quarter

Deposits: $\quad$ Total deposits (COMPUSTAT "dptcq) divided by total loans, at the beginning of the quarter.

$\triangle$ Capital R1: Change in variable Capital $R 1$, beginning tier I capital ratio subtract lagged beginning tier I capital ratio.

$\sigma_{\text {ret }}: \quad$ Standard deviation of daily return of the previous quarter. 
Table 6: Analysis of the effects of capital ratio, recession and stock measure of delay in loss recognition on change in loans for well managed vs. poorly managed banks

\begin{tabular}{|c|c|c|c|}
\hline & & $\begin{array}{c}\text { Well Managed } \\
\text { Banks+ }\end{array}$ & $\begin{array}{c}\text { Poorly Managed } \\
\text { Banks }\end{array}$ \\
\hline Variables & Prediction & $\begin{array}{c}\text { Coefficients } \\
\text { (clustered t-stats) }\end{array}$ & $\begin{array}{c}\text { Coefficients } \\
\text { (clustered t-stats) }\end{array}$ \\
\hline Intercept & $+/-$ & $\begin{array}{c}0.042 \\
(6.55) * * *\end{array}$ & $\begin{array}{l}0.050 \\
(9.01)^{* * *}\end{array}$ \\
\hline$<$ Delay & $+/-$ & $\begin{array}{l}-0.000 \\
(-0.10)\end{array}$ & $\begin{array}{l}-0.006 \\
(-1.85)^{*}\end{array}$ \\
\hline Recession & - & $\begin{array}{l}-0.022 \\
(-2.19) * *\end{array}$ & $\begin{array}{l}-0.034 \\
(-4.85) * * *\end{array}$ \\
\hline Recession*<Delay & + & $\begin{array}{c}0.034 \\
(4.34)^{* * *}\end{array}$ & $\begin{array}{c}0.035 \\
(6.38) * * * \\
\end{array}$ \\
\hline Capital R1 & + & $\begin{array}{l}-0.000 \\
(-0.00)\end{array}$ & $\begin{array}{l}-0.067 \\
(-3.11) * * *\end{array}$ \\
\hline Capital R1 $*<$ Delay & $+/-$ & $\begin{array}{l}0.016 \\
(0.46) \\
\end{array}$ & $\begin{array}{c}0.129 \\
(3.64)^{* * *}\end{array}$ \\
\hline Capital R1* Recession & + & $\begin{array}{c}0.204 \\
(2.18) * *\end{array}$ & $\begin{array}{c}0.306 \\
(4.79) * * *\end{array}$ \\
\hline $\begin{array}{l}\text { Capital R1* Recession } \\
*<\text { Delay }\end{array}$ & - & $\begin{array}{l}-0.254 \\
(-3.24)^{* * *}\end{array}$ & $\begin{array}{l}-0.274 \\
(-5.09) * * *\end{array}$ \\
\hline$\triangle$ UNRATE & - & $\begin{array}{l}-0.016 \\
(-4.33) * * *\end{array}$ & $\begin{array}{l}-0.023 \\
(-4.62) * * *\end{array}$ \\
\hline Size & $+/-$ & $\begin{array}{l}-0.002 \\
(-4.57)^{* * *}\end{array}$ & $\begin{array}{l}-0.002 \\
(-6.76) * * *\end{array}$ \\
\hline Deposits & + & $\begin{array}{c}0.001 \\
(0.93) \\
\end{array}$ & $\begin{array}{l}-0.002 \\
(-0.92) \\
\end{array}$ \\
\hline$\Delta$ Capital R1 & $+/-$ & $\begin{array}{l}-0.193 \\
(-3.41)^{* * *}\end{array}$ & $\begin{array}{l}-0.068 \\
(-1.21) \\
\end{array}$ \\
\hline$\sigma_{r e t}$ & $+/-$ & $\begin{array}{l}-0.099 \\
(-1.23) \\
\end{array}$ & $\begin{array}{r}-0.127 \\
(-1.47) \\
\end{array}$ \\
\hline R-Squared & & 0.0201 & 0.0513 \\
\hline $\mathrm{N}$ & & 8,011 & 7,960 \\
\hline
\end{tabular}

Variable Definitions:

$\Delta$ Loan:

Change in the natural log of loans (COMPUSTAT "Intalq").

$<$ Delay:

An indicator variable equal to one if the lagged ALWN is greater than the median during the quarter, and zero otherwise. ALWN is defined as loan loss allowance (COMPUSTAT "rclq") divided by non-performing assets (COMPUSTAT "npatq”). 
Recession: $\quad$ An indicator variable equal to one for periods between 2001Q2 and 2001Q4, and periods between 2008Q1 and 2009Q2; zero, otherwise.

Capital R1: $\quad$ Tier I risk-adjusted capital ratio (COMPUSTAT "capr1q") at the beginning of the quarter, divided by 100 .

$\triangle$ UNRATE: $\quad$ The change in the quarterly unemployment rate.

Size:

The natural $\log$ of total assets (COMPUSTAT "atq") at the beginning of the quarter.

Deposits: $\quad$ Total deposits (COMPUSTAT “dptcq) divided by total assets.

$\Delta$ Capital R1: $\quad$ Change in variable Capital $R 1$, beginning tier I capital ratio subtract lagged beginning tier I capital ratio.

$\sigma_{r e t}: \quad$ Standard deviation of daily return of the previous quarter. 
Table 7: Analysis of the effect of stock measure of delay in loss recognition on change in common shareholders' equity ( $\triangle \mathrm{CE})$ for well vs. poorly managed banks

\begin{tabular}{|c|c|c|c|}
\hline & & $\begin{array}{c}\text { Well Managed } \\
\text { Banks+ }\end{array}$ & $\begin{array}{c}\text { Poorly Managed } \\
\text { Banks }\end{array}$ \\
\hline Variables & Prediction & $\begin{array}{c}\text { Coefficients } \\
\text { (clustered t-stats) }\end{array}$ & $\begin{array}{c}\text { Coefficients } \\
\text { (clustered t-stats) }\end{array}$ \\
\hline Intercept & $+/-$ & $\begin{array}{l}0.045 \\
(7.11)^{* * * *}\end{array}$ & $\begin{array}{l}0.022 \\
(3.95) * * *\end{array}$ \\
\hline$<$ Delay & + & $\begin{array}{l}0.002 \\
(2.29) * *\end{array}$ & $\begin{array}{l}0.005 \\
(6.93) * * *\end{array}$ \\
\hline Recession & - & $\begin{array}{l}-0.014 \\
(-1.98) * *\end{array}$ & $\begin{array}{l}-0.017 \\
(-2.05)^{* *}\end{array}$ \\
\hline Recession $*<$ Delay & + & $\begin{array}{l}0.005 \\
(1.78) * *\end{array}$ & $\begin{array}{l}0.007 \\
(1.35)^{*}\end{array}$ \\
\hline Capital R1 & $+/-$ & $\begin{array}{l}-0.127 \\
(-6.56) * * *\end{array}$ & $\begin{array}{l}-0.122 \\
(-4.65) * * *\end{array}$ \\
\hline$\triangle \mathrm{UNRATE}$ & $+/-$ & $\begin{array}{l}0.006 \\
(0.94)\end{array}$ & $\begin{array}{l}-0.005 \\
(-0.81)\end{array}$ \\
\hline Size & $+/-$ & $\begin{array}{l}-0.001 \\
(-1.65)\end{array}$ & $\begin{array}{l}0.001 \\
(1.00)\end{array}$ \\
\hline Deposits & $+/-$ & $\begin{array}{l}0.001 \\
(0.49)\end{array}$ & $\begin{array}{l}0.003 \\
(1.21)\end{array}$ \\
\hline R-Squared & & 0.0124 & 0.0321 \\
\hline $\mathrm{N}$ & & 9,496 & 9,461 \\
\hline
\end{tabular}

$* * *, * *$, and $*$ represent $1 \%, 5 \% \& 10 \%$ significance, respectively (two-tailed or one-tailed, as appropriate). +: Well (Poorly) Managed Banks refer to banks have profitability higher (lower) than the median during the quarter, defined as returns before provision (COMPUSTAT "piq" plus "pllq") over lagged total loans (COMPUSTAT "Intalq") calculated at the beginning of the quarter.

Variable Definitions:

$\triangle \mathrm{CE}: \quad$ Measured as the natural log of common shareholders' equity of quarter $\mathrm{t}$ with loan loss provisions added back (COMPUSTAT "ceqq" +0.6* COMPUSTAT "pllq") minus the natural log of lagged common shareholders' equity (COMPUSTAT "ceqq" at quarter $\mathrm{t}-1$ ).

<Delay: $\quad$ An indicator variable equal to one if the lagged ALWN is greater than the median during the quarter, and zero otherwise. ALWN is defined as loan loss allowance (COMPUSTAT "rclq") divided by non-performing assets (COMPUSTAT "npatq").

Recession: An indicator variable equal to one for periods between 2001Q2 and 2001Q4, and periods between 2008Q1 and 2009Q2; zero, otherwise.

Capital R1: $\quad$ Tier I risk-adjusted capital ratio (COMPUSTAT "capr1q") at the beginning of the quarter, divided by 100.

$\triangle$ UNRATE: $\quad$ The change in the quarterly unemployment rate. 
Size:

Deposits:
The natural log of total assets (COMPUSTAT "atq") at the beginning of the quarter.

Total deposits (COMPUSTAT “dptcq) divided by total loans, at the beginning of the quarter. 
Table 8: Analysis of the effects of primary capital ratio and recession on change in loans in preregulatory (1961:1-1981:3) and Basel periods (1993:4-2009:2)

\begin{tabular}{|c|c|c|c|}
\hline & & Pre-Regulatory Period & Basel Period \\
\hline & Prediction & $\begin{array}{c}\text { Coefficients } \\
\text { (clustered t-stat) }\end{array}$ & $\begin{array}{c}\text { Coefficients } \\
\text { (clustered t-stat) }\end{array}$ \\
\hline Intercept & $+/-$ & $\begin{array}{l}0.008 \\
(0.46)\end{array}$ & $\begin{array}{c}0.032 \\
(7.18) * * *\end{array}$ \\
\hline Recession & - & $\begin{array}{l}0.0127 \\
(1.36) \\
\end{array}$ & $\begin{array}{l}-0.003 \\
(-0.76)\end{array}$ \\
\hline Primary Capital Ratio & + & $\begin{array}{l}-0.071 \\
(-1.07) \\
\end{array}$ & $\begin{array}{l}0.016 \\
(1.35)\end{array}$ \\
\hline $\begin{array}{l}\text { Recession *Primary } \\
\text { Capital Ratio }\end{array}$ & + & $\begin{array}{l}-0.113 \\
(-1.47) \\
\end{array}$ & $\begin{array}{c}0.054 \\
(1.65)^{*}\end{array}$ \\
\hline$\triangle \mathrm{UNRATE}$ & - & $\begin{array}{c}-0.024 \\
(-2.54) * *\end{array}$ & $\begin{array}{c}-0.021 \\
(-4.74) * * *\end{array}$ \\
\hline Size & $+/-$ & $\begin{array}{c}0.004 \\
(3.27)^{* * *}\end{array}$ & $\begin{array}{c}-0.001 \\
(-3.79) * * *\end{array}$ \\
\hline Deposits & + & $\begin{array}{l}0.005 \\
(1.33)\end{array}$ & $\begin{array}{c}0.003 \\
(2.17)^{* *}\end{array}$ \\
\hline $\begin{array}{l}\Delta \text { Primary Capital } \\
\text { Ratio }\end{array}$ & $+/-$ & $\begin{array}{c}0.953 \\
(1.84)^{*}\end{array}$ & $\begin{array}{c}-0.206 \\
(-2.56) * *\end{array}$ \\
\hline$\sigma_{r e t}$ & $+/-$ & $\begin{array}{c}-1.444 \\
(-5.25) * * *\end{array}$ & $\begin{array}{l}-0.106 \\
(-1.36)\end{array}$ \\
\hline R-Squared & & 0.1609 & 0.0209 \\
\hline $\mathrm{N}$ & & 3,940 & 21,211 \\
\hline
\end{tabular}

$* * *, * *$, and $*$ represent $1 \%, 5 \%$ and $10 \%$ significance, respectively.

Variable Definition:

$\Delta$ Loan:

Recession:

Change in the natural log of loans (COMPUSTAT "Intalq").

An indicator variable equal to one for periods 1970 Q1 - 1970 Q4, 1974 Q1 - 1975 Q1, 1980 Q1 - 1980 Q3, 2001Q2 - 2001Q4, and 2008Q1 - 2009Q2; zero, otherwise.

$\triangle$ Loan: $\quad$ Change in the natural log of loans (COMPUSTAT "Intalq").

Primary Capital Ratio: the sum of common shareholder equity (COMPUSTAT "ceqq") plus preferred shareholder equity (COMPUSTAT “pstkq”) minus goodwill (COMPUSTAT “gdwlq"), scaled by total assets.

$\triangle$ UNRATE: $\quad$ the change in the quarterly unemployment rate.

Size: the natural log of total assets (COMPUSTAT "atq").

Deposits: total deposits (COMPUSTAT “dptcq) divided by total loans, at the beginning of the quarter.

$\Delta$ Primary Capital Ratio: Change in Primary Capital Ratio.

$\sigma_{r e t}: \quad \quad$ Standard deviation of daily return of the previous quarter. 
Table 9: Analysis of the effects of capital ratio, recession, and delay in expected loss recognition on change in loans, using alternative flow measure in which expected losses are predicted values of future and concurrent nonperforming loans based on macro-variables

\begin{tabular}{|l|c|c|c|}
\hline Variable & Prediction & Coefficients & Clustered t-stats \\
\hline Intercept & $+/-$ & 0.036 & $7.89^{* * *}$ \\
\hline$<$ Delay & $+/-$ & -0.004 & -1.35 \\
\hline Recession & - & -0.022 & $-3.12^{* * *}$ \\
\hline Recession*<Delay & + & 0.015 & $2.27^{* *}$ \\
\hline Capital R1 & + & -0.026 & -0.93 \\
\hline Capital R1 *<Delay & $+/-$ & 0.047 & 1.67 \\
\hline Capital R1* Recession & + & 0.231 & $4.00^{* * *}$ \\
\hline Capital R1*Recession*<Delay & - & -0.147 & $-2.45^{* * *}$ \\
\hline$\Delta$ UNRATE & - & -0.016 & $-3.64^{* * *}$ \\
\hline Size & $+/-$ & -0.001 & $-3.59^{* * *}$ \\
\hline Deposits & + & 0.001 & 0.69 \\
\hline$\Delta$ Capital R1 & $+/-$ & -0.070 & -1.10 \\
\hline$\sigma_{\text {ret }}$ & $+/-$ & -0.159 & -1.60 \\
\hline $\mathrm{R}-$ Squared & & 0.0242 & \\
\hline $\mathrm{N}$ & & 8,128 & \\
\hline
\end{tabular}

$* * *, * *$, and $*$ represent $1 \%, 5 \% \& 10 \%$ significance, respectively (two-tailed or one-tailed, as appropriate).

Variable Definition:

$\Delta$ Loan: Change in the natural log of loans (COMPUSTAT "Intalq").

$<$ Delay (Flow Measure):An indicator variable equal to one if the lagged delay measure is greater than the median during the quarter, where the delay measure is the difference in adjusted $\mathrm{R}$-squared (EQ2-EQ1) from the following two rolling regressions for each bank-quarter using the observations of the past 3 years. We require 12 observations in each regression.

EQ1: Provision $_{t}=\alpha_{0}+\alpha_{1} \Delta N P L_{t-2}+\alpha_{2} \Delta N P L_{t-1}+\alpha_{3}$ Capital R $_{t}+\alpha_{4} * E B P_{t}+\varepsilon_{t}$

EQ2: Provision $_{t}=\alpha_{0}+\alpha_{1} \Delta N P L_{t-2}+\alpha_{2} \Delta N P L_{t-1}+\alpha_{3} P R E\left(\Delta N P L_{t}\right)+\alpha_{4} P R E\left(\Delta N P L_{t+1}\right)$

Where

$$
+\alpha_{5} \text { Capital RI } 1_{t}+\alpha_{6} E B P_{t}+\varepsilon_{t}
$$

Provision $=$ Loan loss provision (COMPUSTAT "pllq") divided by lagged total loans (COMPUSTAT "Intalq");

$\triangle \mathrm{NPL}=$ Change in non-performing assets (COMPUSTAT "npatq") divided by lagged total loans (COMPUSTAT "Intalq");

$\mathrm{EBP}=$ earnings before loan loss provision, defined as (COMPUTAT "piq" plus COMPUSTAT "pllq", scaled by lagged COMPUSTAT "lntalq").

PRE $(\triangle \mathrm{NPL})=$ Predicted value of change in non-performing loans using the bank-level regression of $\triangle \mathrm{NPL}$ on concurrent and lagged values of the change in unemployment rate and industrial production index published by FED. 
Recession: An indicator variable equal to one for periods between 2001Q2 and 2001Q4, and periods between 2008Q1 and 2009Q2; zero, otherwise.

Capital R1: Tier I risk-adjusted capital ratio (COMPUSTAT "capr1q") at the beginning of the quarter, divided by 100 .

$\triangle$ UNRATE: The change in the quarterly unemployment rate.

Size: The natural log of total assets (COMPUSTAT "atq") at the beginning of the quarter.

Deposits: $\quad$ Total deposits (COMPUSTAT “dptcq) divided by total loans, at the beginning of the quarter.

$\Delta$ Capital R1: Change in variable Capital R1, beginning tier I capital ratio subtract lagged beginning tier I capital ratio.

$\sigma_{\text {ret }}: \quad$ Standard deviation of daily return of the of the previous quarter. 